\title{
Late Jurassic-Early Cretaceous foraminifera from Štramberk-type limestones, Polish Outer Carpathians
}

\author{
Daria IVANOVA ${ }^{*}$ \& Bogusław KOÆ ODZIEJ ${ }^{2}$ \\ ${ }^{1}$ Geological Institute, Bulgarian Academy of Sciences, Acad. G. Bonchev Str., B1. 24, 1113 Sofia, Bulgaria \\ ${ }^{2}$ Institute of Geological Sciences, Jagiellonian University, Oleandry 2a Str., 30-063 Kraków, Poland
}

Received February 2010; accepted July 2010

Available online 7 August 2010

DOI: $10.5038 / 1937-8602.55 .2 .1$

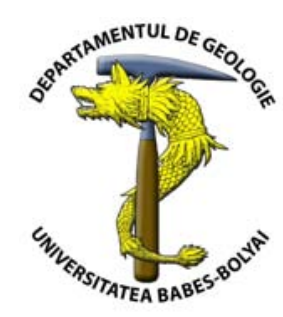

\begin{abstract}
Foraminifera studies were carried out on the Štramberk-type limestones which occur as pebbles to small boulders (exotics) within the uppermost Jurassic-Palaeogene flysch deposits of the Polish Outer Carpathians. The studies were focused on foraminifera from (1) reef and peri-reef facies, and (2) lagoonal algal-foraminiferal facies. The paper deals with 34 species (including 8 in open nomenclature) representing 30 genera, 22 families, 14 superfamilies, 11 suborders, and 7 orders. A more precise age determination has been obtained for 30 exotics, representing a Tithonian (mostly) to Valanginian age. Foraminiferal assemblages from at least two exotics suggest a Valanginian age as indicated by the co-occurrence of the species: Meandrospira favrei (CHAROLLAIS, BRÖNNIMANN \& ZANINETTI), Montsalevia salevensis (CHAROLLAIS, BRÖNNIMANN \& ZANINETTI), Patellina turriculata DIENI \& MASSARI, Neotrocholina valdensis REICHEL, Hechtina praeantiqua BARTENSTEIN \& BRAND, Istriloculina eliptica (IOVCHEVA) and I. emiliae NEAGU. Previous studies based on ammonites and calpionellids indicated the Tithonian to the Early Berriasian age of the Štramberk Limestone in Moravia (the Czech Republic), and their equivalents in Poland. However, Valanginian shallow-water limestones occur as pebbles in some deposits of the Outer Carpathians in the Czech Republic. Further evidence for Valanginian shallow-water marine carbonate sedimentation (algal facies) in the Polish part of the Tethyan margin comes from recent studies of the substrate drilled in the Carpathian Foredeep.
\end{abstract}

Key words: Foraminifera, Upper Jurassic, Lower Cretaceous, Štramberk-type limestones, Outer Carpathians, Poland.

\section{INTRODUCTION}

During the Late Jurassic and earliest Cretaceous, sedimentation in the Polish segment of the northern Tethyan margin developed on a carbonate platform affected by block tectonics. In the Outer Carpathians these deposits occur within the uppermost Jurassic-Palaeogene flysch deposits as so-called exotics - pebbles, cobbles and boulders, rarely klippes (e.g., Inwałd near Wadowice, Kruhel near Przemyśl).

Like the Stramberk Limestone from type localities in Moravia (Czech Republic), Štramberk-type limestones are often developed in reefal facies. In fact, these limestones represent more diverse facies of a carbonate platform. The Tithonian-early Berriasian age of the Štramberk Limestone in Moravia, and its equivalent in Poland, is evidenced by ammonites and calpionellids (e.g., Morycowa, 1988; Houša, 1990; Eliáš and Vašíček, 1995; Ciborowski and Kołodziej, 2001). However some biostratigraphical studies indicate that Valanginian shallow-water limestones occur as pebbles in the Outer Carpathians (Soták and Mišík 1993; Ivanova and Kolodziej, 2004). Further evidence of Valanginian shallowwater sedimentation on the northern shelf of the Polish and Czech segment of the Tethyan northern platform comes from boreholes in the middle part of the Polish Carpathian Foredeep (Foreland) (e.g., Gutowski et al., 2007; Matyja, 2009).

*Correspondence: D. Ivanova (dariaiv@geology.bas.bg)
To date foraminifera from the Štramberk-type limestones of the Polish Outer Carpathians have not been the subject of detailed analysis. Previous studies were mainly performed during microfacies analyses, rarely in terms of biostratigraphy, and dealt with limited samples (Geroch and Morycowa, 1966; Kołodziej, 1997; Decrouez and Morycowa, 1997; Kołodziej and Decrouez, 1997; Olszewska and Wieczorek, 2001; Król and Decrouez, 2002; Ivanova and Kolodziej, 2004). Recently Olszewska (2005) described the foraminifera from the Tithonian-Valanginian Cieszyn Limestones, which are a deepwater equivalent of the Štramberk carbonates.

In the present paper the boring foraminifera Troglotella incrustans WERNLI \& FOOKES, 1992, nubecularids, and microproblematica, e.g. Crescentiella (= "Tubiphytes") morronensis (CRESCENTI, 1969) (see Senowbari-Daryan et al., 2008) interpreted by some authors as foraminifera, are not described. The representatives of the genera Trocholina and Neotrocholina (subfamily Involutininae) will be the subject of another paper.

\section{GEOLOGICAL CONTEXT}

Sedimentation of the Štramberk Limestone from Moravia and the Štramberk-type limestones from the Polish 
Outer Carpathians developed on a carbonate platform along the northern Tethyan margin affected by the Late Jurassic/Early Cretaceous block tectonics (e.g., Brno Platform, Pavlov Platform; Eliáš and Eliášová, 1984, 1986; Vašíček et al., 1994; Golonka et al., 2000).

These limestones, traditionally assumed as reefal, are in fact represented by diversified facies of a carbonate platform. For instance, Książkiewicz (1971) recognized that the Inwałd limestones (the local name for the Stramberktype limestones from the Inwałd klippe near Wadowice) represent deposits of shoals with reef bordering bahamite deposits. Among the Andrychów Klippes occur also other Jurassic carbonates: Callovian crinoidal limestones, and Oxfordian cherty limestones with Saccocoma (Książkiewicz, 1935; Nowak, 1976; Olszewska and Wieczorek, 2001).

Hoffmann \& Kołodziej $(2004,2008)$ have distinguished six main facies represented in exotics of Stramberk-type limestones: (1) coral-microbial boundstones, (2) spongemicrobial boundstones, (3) poorly sorted bioclastic grainstones to rudstones being fragments of coral-debris pile reefs or talus of coral-microbial boundstones, (4) foraminiferal-algal packstones to grainstones, (5) bioclastic wackestones/packstones, and (6) peloidal wackestones. Some of the facies, e.g. marls, might not be preserved as exotics due to their lower fossilization potential.

Establishing spatial and temporal relationships between different facies on the basis of exotics is difficult or impossible. Hoffmann and Kołodziej (2008) presented a generalized interpretation of the sedimentary environment of the studied limestones. This model assumes that on the margin of carbonate platforms high-energy debris reefs were developed. Within the inner part of the platform, coralmicrobial patch reefs were formed, however it was foraminiferal-algal facies and peloidal-bioclastic wackestones/packstones that were mainly deposited there. Microbial or sponge-microbial boundstones are much less common than coral facies and their age is unknown. They can be a deeper water equivalent of shallow-water reefs. They can also represent Oxfordian sponge megafacies known from the Cracow Upland, and from boreholes in the Carpathian Foredeep. However, according to Barski and Matyja (2008) and Matyja (2009) this megafacies was formed in the area of the present Carpathian Foredeep as late as the Early Tithonian. Within narrow basins between the North European Plate and carbonate platforms deepwater sedimentation including allodapic limestones (e.g., Cieszyn Limestone) took place (Malik, 1986; Słomka, 1986; Matyszkiewicz and Słomka, 2004; Olszewska, 2005).

The source areas of exotics, not outcropping now, represent the basement of flysch deposits: periodically emerged and eroded marginal parts (known from wells in the Carpathian Foredeep) of the flysch basins or intrabasinal ridges (socalled cordilleras; Książkiewicz, 1965).

The present paper deals with foraminifera from limestones representing two facies (based on the interpretation of exotics usually dozen or so centimeters in diameter) where foraminifera are common, namely (1) coral-microbial boundstones, and (2) algal-foraminiferal grainstones. Both facies were recently the subject of detailed studies with respect to benthic algae (Bucur et al., 2005). Unequivocal attribution to one of these two main facies is sometimes problematic, but most studied limestones represent the second facies.
Coral-microbial boundstones are composed of diversified corals, microbialites, and microencrusters (including the encrusting microproblematicum Crescientella morronenis (Crescenti) and nubecularid foraminifera). Corals are numerous and diversified (e.g., Morycowa, 1964, 1968, 1974; Kołodziej, 2003), commonly bored by the foraminifer Troglotella incrustans (see Kołodziej, 1997). The latter is commonly associated with microproblematicum Lithocodium aggregatum Elliott, interpreted recently as the foraminifer (Schmid and Leinfelder, 1996) or calcimicrobs (Cherchi and Schroeder, 2006). Locally, microencrusters and synsedimentary cement played an important role in the formation of the reef framework (Hoffmann et al., 2008). Such a framework seems to be characteristic for margins of isolated platforms in the Tethyan domain (Schlagintweit and Gawlick, 2008). Common growth cavities are filled with bioclastic grainstones. Coral-microbial boundstones contain the benthic algae Thaumatoporella parvovesiculifera (RAINERI), Nipponophycus ramosus YABE \& TOYAMA, Neoteutloporella socialis (PRATURLON), and other fragments of Dasycladales, rare solenoporaceans including Marinella lugeoni PFENDER (Bucur et al., 2005).

The algal-foraminiferal facies consists of bioclastic grainstones and packstones. Grain particles are often superficially micritised. The faunal community is dominated by dasycladacean algae (19 species), rivulariacean-like cyanobacteria (Bucur et al., 2005), and benthic foraminifera. Bioclasts are commonly encrusted by Lithocodium-Bacinella.

\section{MATERIAL}

The studied foraminifera were collected from pebbles, cobbles and small boulders of the Štramberk-type limestones from several localities of the Silesian, SubSilesian and Skole units (Fig. 1). The localities and stratigraphic position of exotic-bearing flysch deposits with relation to the Outer Carpathian nappes are given below. More than 360 thin sections from nearly 200 exotics were studied. Exotics and thin sections are deposited in the Geological Museum of the Institute of Geological Sciences, Jagiellonian University, Kraków (collection (UJ 140 P). The second number (e.g., 78 in $140 \mathrm{P} / 78$ ) refers to the number of exotic pebble/boulder.

\section{Silesian nappe}

1 - Zamarski - $6 \mathrm{~km}$ north from Cieszyn; Lower Cieszyn Beds (Kimmeridgian-middle Upper Tithonian).

2 - stream in Leńcze village, $5 \mathrm{~km}$ north of Kalwaria Zebrzydowska; Lower Istebna Beds (Late Senonian).

3 - Gródek nad Dunajcem (Gródek upon Dunajec), Rożnów Lake, 15 km north of Nowy Sącz; Ciężkowice Beds (Eocene).

\section{Sub-Silesian nappe}

4 - Krzywa stream in Lusina village (perviously localized as Krzywica village - Kołodziej, 2003), 7 km west of Skawina; Verovice Beds (Barremian).

5 - Jastrzębia stream in Jastrzębia village, $1.5 \mathrm{~km}$ east of Lanckorona; Grodziszcze Beds (Early Aptian).

6 - Rędzina stream in Woźniki village, $6 \mathrm{~km} \mathrm{~N}$ of Wadowice; black shales within Gaize Beds (Late Aptian-Albian).

\section{Skole nappe}

7 - Lubeńka stream in Lubenia village, $12 \mathrm{~km}$ south-east of Rzeszów, Babica Clays (Upper Paleocene). 


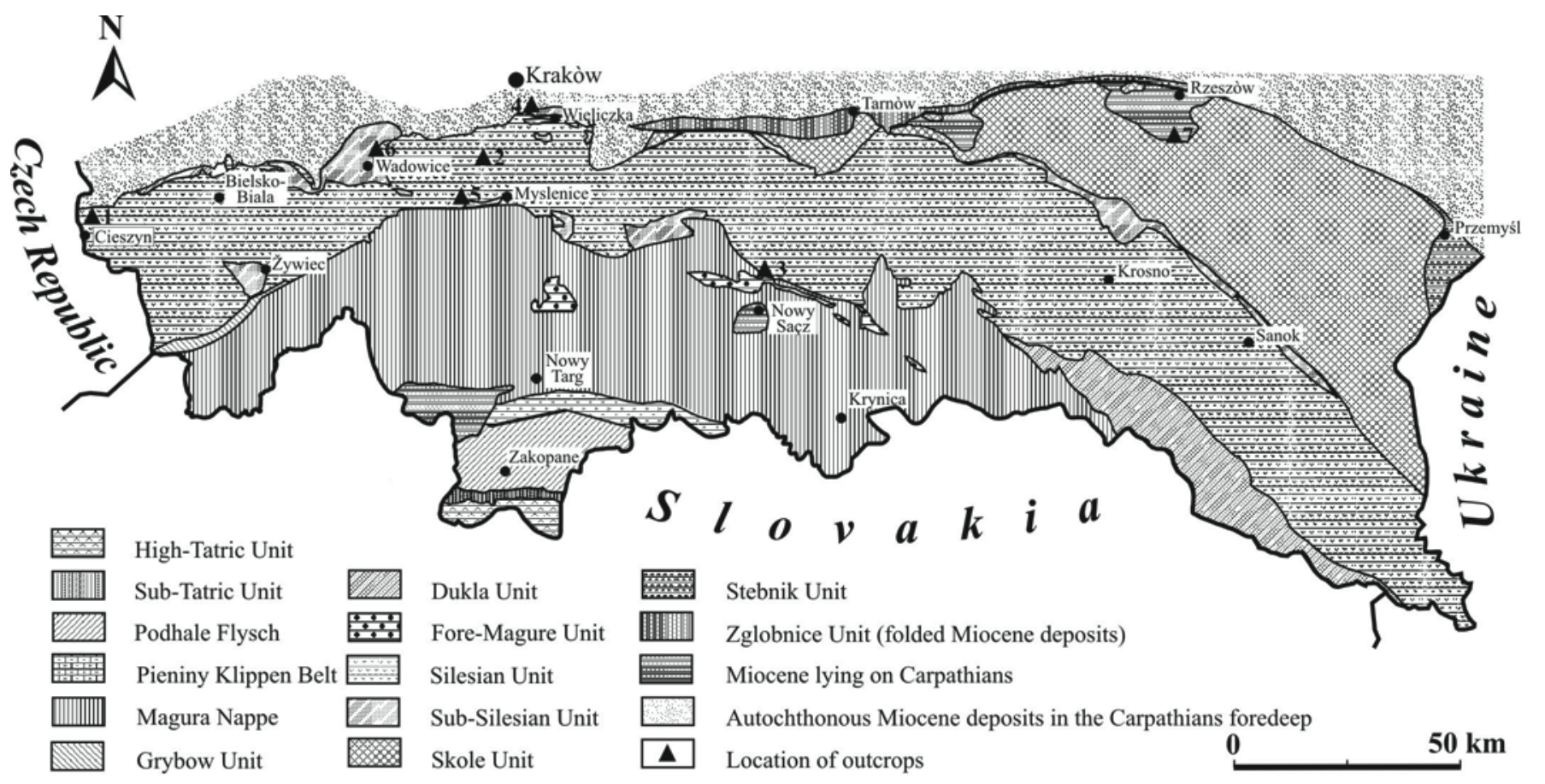

Fig. 1. Geological map of the Polish Carpathians (based on Malata et al., 1996) with position of localities with analysed exotics.

\section{BIOSTRATIGRAPHIC RESULTS}

Thirthy-four foraminiferal species (including 8 in open nomenclature) representing 30 genera, 22 families, 14 superfamilies, 11 suborders, and 7 orders were recognized in the studied limestones. In consequence of the detailed taxonomical and biostratigraphical micropaleontological investigation the age of the studied exotic blocks fits within the late Tithonian to early Valanginian interval. Although foraminifera from nearly 200 exotics were studied, a more precise age determination was obtained for only for 30 of them.

According to the generalized stratigraphic range of the foraminifera species given in Chapter 6 the following age of the exotics were determined:

2 exotics - not older than Tithonian

13 exotics - not older than late Tithonian

6 exotics - not older than Berriasian

7 exotics - not older than late Berriasian

2 exotics - not older than Valanginian

Among exotics whose age was estimated as not older than Tithonian or Berriasian 27 exotics contain foraminifera with stratigraphic range exceeding the Berriasian (sometimes there are exotics containing only one determined species).

Although the species mentioned below were not found together in one exotic their first appearances mark the age of the exotics, where they were established. Accordingly the present study, the lower boundary of some exotics is determined as Upper Tithonian based on the presence of the species: Nautiloculina bronnimanni ARNAUD-VANNEAU \& PEYBERNÉS, Coscinophragma cribrosum (REUSS), Charentia cuvillieri NEUMANN, and Protopeneroplis ultragranulata (GORBACHIK). The Berriasian age is documented by presence of the species: Melathrokerion valserinensis BRÖNNIMANN \& CONRAD, Mayncina $\mathrm{cf}$. bulgarica LAUG, PEYBERNÉS \& REY, Dobrogelina ovidi NEAGU, Hechtina praeantiqua BARTENSTEIN \& BRAND, Moesiloculina danubiana NEAGU, Istriloculina eliptica (IOVCHEVA), I. emiliae NEAGU, as well as an appearance of a very rich association of representatives of the genera Trocholina and Neotrocholina (Arnaud-Vanneau et al., 1988; Mancinelli and Coccia, 1999). Supporting evidence for a Valanginian age of some exotic blocks is found in the presence of the association: Meandrospira favrei (CHAROLLAIS, BRÖNNIMANN \& ZANINETTI), Montsalevia salevensis (CHAROLLAIS, BRÖNNIMANN \& ZANINETTI), Patellina turriculata DIENI \& MASSARI, Neotrocholina valdensis REICHEL, Hechtina praeantiqua BARTENSTEIN \& BRAND, Istriloculina eliptica (IOVCHEVA) and I. emiliae NEAGU. Despite some of these species possessing a wider range as an association they clearly show Valanginian age.

A Tithonian, mainly late Tithonian, age is assumed for the Štramberk Limestone (Moravia) and Štramberk-type limestones (Poland), however both ammonites and calpionellids provide evidence for an early Berriasian age as well (e.g., Morycowa, 1968; Houša, 1990; Eliáš and Vašíček, 1995; Ciborowski and Kołodziej, 2001). Evidence for a Valanginian age for coral-bearing limestones provided by previous studies of foraminifera (Ivanova and Kołodziej, 2004), and herein. However, all available data indicate that although shallow-water sedimentation persisted through the Valanginian, the main coral reef development occurred in the Late Tithonian and less extensively in the Early Berriasian. The Berriasian stage is represented by exotics that can be attributed mainly to lagoonal, algal-foraminiferal facies.

It should be emphasized that shallow-water limestones of Valanginian age were recognized in the Outer Carpathians in the Czech Republic. They occur as pebbles within conglomerates in the Ždanice unit and Magura 
Group, and represent the Berriasian to Valanginian Clypeina-limestones (with detritus of reefal organisms), and the Berriasian to Valanginian Bacinella biolithites and perireefal rudstones (Soták and Mišík, 1993). Further evidence for Valanginian shallow-water marine carbonate sedimentation in the Polish part of the Tethyan margin comes from recent studies of the substrate drilled in the Carpathian Foredeep (see next chapter).

\section{SUBSURFACE EQUIVALENTS OF THE ŠTRAMBERK-TYPE LIMESTONES IN POLAND OUTSIDE OF THE CARPATHIANS}

Lower Cretaceous deposits were known in the Polish Carpathian Foredeep (e.g., Moryc, 1997). However, until the end of the 1990s, Tithonian-lowermost Cretaceous facies equivalents of Štramberk-type limestones were not recognized in this area. New wells drilled in the middle part of the Carpathian Foredeep have provided new data and allowed a revision of the biostratigraphy. On the basis of calpionellids, calcareous and organic dinocysts, as well as foraminifera deposits previously not known or determined as Oxfordian-Kimmeridgian were established as TithonianValanginian (Olszewska, 1999, 2001; Maksym et al., 2001; Zdanowski et al., 2001; Urbaniec and Świetlik, 2003; Bobrek et al., 2005; Gutowski et al., 2007; Barski and Matyja, 2008; Matyja, 2009; Urbaniec et al., in review; see also Świdrowska et al., 2007). In spite of some differences in biostratigraphy and lithostratigraphy presented by Polish research groups, the presence of Tithonian-Valanginian shallow water carbonates in the Carpathian Foreland is now firmly established. They are represented by diverse facies of carbonate platform including reefs.

Coral-bearing limestones from the northern part of the Carpathian Foreland may represent the Upper OxfordianLower Kimmeridgian (Morycowa and Moryc, 1976; Gutowski et al., 2007), although according to Barski and Matyja (2008) and Matyja (2009) they represent the Tithonian as indicated by organic dinocysts. An age of late early Tithonian or early late Tithonian of coral reefs in the southern part of the middle part of the Carpathian Foreland (drillings in Pilzno area) was given by calpionellids (Matyja, 2009) and foraminifers (Urbaniec and Świetlik, 2003, Urbaniec et al., in review). The reefal limestones from the southern region are a lateral equivalent to coral reefs known from Štramberk Limestone (Matyja, 2009). However, the lack of more detailed data on these reefs makes impossible a direct comparison with the Stramberk Limestone with respect to lithology and coral assemblages (unique coral fauna in the Štramberk Limestone and exotics). Both the corals and lithology of coral-bearing limestones from the northern part of the Carpathian Foreland (Morycowa and Moryc, 1976; Morycowa, 1985) differ from those known from the Štramberk Limestone and exotics.

Valanginian shallow water deposits, mainly limestones, represent an inner and outer lagoon (including ooidalbioclastic limestones of high energy shoals). Bioclastic detritus contains coral fragments (Urbaniec and Świetlik, 2003; Bobrek et al., 2005; Urbaniec et al., in review).

The nearest outcrops where shallow water facies, an age equivalent of the Štramberk-type limestones, occur in situ is in the Niżniów (Nyzhniv) region in the Western Ukraine (Gutowski et al., 2005b). The upper Tithonian-lower
Berriasian Niżniów Formation is regarded by Gutowski et al. (2005a) as the stratigraphic equivalent of the Late Kimmeridgian-Lower Berriasian Babczyn Formation („Portlandian” according to Niemczycka, 1976a, b) recognized in boreholes in the Lublin Upland, SE Poland. These are developed mostly as bioclastic limestones; extensive reef development is not known.

\section{SYSTEMATIC PART}

The taxonomic determination of the foraminifers is based on the latest changes in the foraminiferal classifications: Loeblich and Tappan, 1987; Loeblich and Tappan, 1992 and Kaminski, 2004 and takes into account the following: Charollais et al., 1966; Hottinger, 1967; Neagu, 1968, 1970 a, b, 1979, 1984, 1985, 1986, 1999; Septfontaine, 1974, 1977, 1980, 1988; Darsac, 1983; Loeblich and Tappan, 1985; Bucur, 1988, 1993, 1997; Bucur et al., 1995, 2004; Schlagintweit et al., 2005 and others.

Class Foraminiferea D’ORBIGNY, 1826

Order Lituolida LANKESTER, 1885

Suborder Lituolina LANKESTER, 1885

Superfamily Lituolacea DE BLAINVILLE, 1827

Family Lituolidae DE BLAINVILLE, 1827

Subfamily Ammomarginulinae PODOBINA, 1978

Genus Ammobaculites CUSHMAN, 1910

Ammobaculites subcretaceus CUSHMAN \&

ALEXANDER, 1930. P1. 1, Figs. 14, 15

*1930 Ammobaculites subcretacea CUSHMAN \&

ALEXANDER, p. 6, P1. 2, Figs. 9, 10.

1990 Ammobaculites subcretaceus CUSHMAN \&

ALEXANDER, Weidich p. 92, P1. 2, Figs. 13-16

(Synonymy).

1991 Ammobaculites subcretaceus CUSHMAN \&

ALEXANDER, Schmalzriedt p. 100, P1. 5, Fig. 6

(Synonymy).

Material: Woźniki (140P/31); Zamarski (140P/36); Lusina (140P/52).

Description: The test is of medium size, elongate with well developed small initial coil made up of seven chambers followed by an enrolled stage composed of maximum four chambers, rounded in section; smooth to gently lobate periphery; the wall is finely agglutinated, aperture terminal.

Distribution: Hauterivian - Cenomanian of the Northern Calcareous Alps (Weidich, 1990); Oxfordian to Lower Kimmeridgian of the western Swabian Alb, Southwestern Germany (Schmalzriedt, 1991).

Known range: Oxfordian (Schmalzriedt, 1991) -

Cenomanian (Weidich, 1990).

Suborder Spiroplectamminina MIKHALEVICH, 1992

Superfamily Spiroplectamminacea CUSHMAN, 1927

Family Textulariopsidae LOEBLICH \& TAPPAN, 1982

Genus Haghimashella NEAGU \& NEAGU, 1995

Haghimashella arcuata (HAEUSLER, 1890) P1. 1, Fig. 17

*1890 Bigenerina arcuata HAEUSLER p. 73, P1. 12,

Figs. 5-7 (non: P1. 11, Fig. 39).

1988 Bigenerina arcuata HAEUSLER, Riegraf p. 472, P1. 5, Figs. 14, 15 (Synonymy)

1989a Bigenerina arcuata HAEUSLER, Riegraf and Luterbacher p. 1026, P1. 2, Figs. 12-14.

1991 Bigenerina arcuata HAEUSLER, Schmalzriedt p. 107, P1. 3, Fig. 10; Pl. 7, Figs. 4-9 (Synonymy). 
1995 Haghimashella arcuata (HAEUSLER), Neagu and Neagu p. 216, P1. 2, Figs. 1-11.

2007 Haghimashella arcuata (HAEUSLER), Krajewski and Olszewska p. 295, Fig. 4 D.

Material: Gródek nad Dunajcem (140 P/109).

Description: Haghimashella arcuata possess elongate test with early biserial stage, later becoming uniserial where four globular chambers are visible; the wall is agglutinated, compact and non-canaliculated.

Remarks: See Neagu and Neagu (1995) for detailed description and arguments for the creation of the genus.

Distribution: Oxfordian of the Swiss Jura (Haeusler, 1890); Middle Callovian-Lower Oxfordian of Sothwestern Germany (Riegraf, 1988); Callovian-Valanginian of Northern Atlantic Ocean (Riegraf and Luterbacher, 1989a); Oxfordian to Lower Kimmeridgian of the western Swabian Alb, Southwestern Germany (Schmalzriedt, 1991); Kimmeridgian-Lower Tithonian of Eastern Carpathians, Romania (Neagu and Neagu, 1995); Upper OxfordianLower Berriasian of the Southern part of the Crimea Mts., Southern Ukraine (Krajewski and Olszewska, 2007).

Known range: Middle Callovian (Riegraf, 1988) Valanginian (Riegraf and Luterbacher, 1989a).

Genus Plectinella MARIE, 1956

Plectinella sp. P1. 1, Fig. 18

Material: Gródek nad Dunajcem (140 P/100)

Description: The observed sections possess a biserial arrangement of the test, slightly twisted; the chambers are relatively high; the wall is solid, agglutinated, and noncanaliculate.

Suborder Verneuilinina MIKHALEVICH \& KAMINSKI, 2004

Superfamily Verneuilinacea CUSHMAN, 1911

Family Prolixoplectidae LOEBLICH \& TAPPAN, 1985

Genus Protomarssonella DESAI \& BANNER, 1987

Protomarssonella kummi (ZEDLER, 1961). Pl. 1, Figs. 11, 12

*1961 Marssonella kummi, ZEDLER p. 31, P1. 7, Fig. 1. 1989b Protomarssonella kummi (ZEDLER), Riegraf and Luterbacher p. 1096, Pl. 3, Figs. 6-7.

1992 Protomarssonella kummi (ZEDLER), Jones and Wonders p. 563, P1. 1, Fig. 20.

2005 Protomarssonella kummi (ZEDLER), Olszewska p.

34, P1. 5, Fig. 5.

Material: Lusina (140 P/67); Gródek nad Dunajcem (140 $\mathrm{P} / 91)$.

Description: Protomarssonella kummi is characterized by its conical, circular in transverse section test; the early stage is trochospiral followed by a biserial stage of rapidly increasing diameter; the terminal face is flattened to concave; the wall is agglutinated.

Remarks: See discussion for the synonymy in Riegraf and Luterbacher (1989b).

Distribution: Lower Hauterivian of Northwest Germany (Zedler, 1961); Valanginian-Albian of the Northern Atlantic Ocean (Riegraf and Luterbacher, 1989b); ValanginianHauterivian of the Barrow Group, Northwest shelf, Australia (Jones and Wonders, 1992); ?Upper Tithonian-Hauterivian of the Cieszyn Limestones Beds, Polish Outer Carpathians (Olszewska, 2005).

Known range: ?Upper Tithonian (Olszewska, 2005) Albian (Riegraf and Luterbacher, 1989b).

Family Verneuilinidae CUSHMAN, 1911

Subfamily Verneuilinoidinae SULEYMANOV, 1973

Genus Gaudryinopsis PODOBINA, 1975
Gaudryinopsis sp. Pl. 1, Figs 9, 10

Material: Zamarski (140 P/36); Lusina (140 P/39)

Description: The observed sections possess an elongate test with a short early triserial stage, later biserial and with nearly parallel sides; the chambers are slightly apprised and sutures are depressed (visible in P1. 1, Fig. 10); the wall is finely agglutinated, simple; aperture is not visible.

Genus Verneuilinoides LOEBLICH \& TAPPAN, 1949

Verneuilinoides neocomiensis (MJATLIUK, 1939). P1. 1, Figs. 1-5

*1939 Verneuilinoides neocomiensis, MJATLIUK p. 50, P1. 1, Figs. 12, 13.

1974 Verneuilinoides neocomiensis (MJATLIUK),

Kuznetsova, P1. 1, Figs. 6 a-c.

1983 Verneuilina cf. polonica CUSHMAN \&

GLAZEWSKI, Darsac p. 210, P1. 5, Fig. 21.

1989b Verneuilinoides neocomiensis (MJATLIUK), Riegraf and Luterbacher p. 1093, P1. 2, Figs. 10-12 (Synonymy).

1992 Verneuilinoides neocomiensis (MJATLIUK),

Kaminski et al., p. 256, P1. 7, Fig. 13.

1992 Verneuilinoides neocomiensis (MJATLIUK), Jones and Wonders p. 563, P1. 1, Fig. 21.

2007 Verneuilinoides polonicus (CUSHMAN \&

GLAZEWSKI), Krajewski and Olszewska p. 297, Fig. 8 B.

Material: Woźniki (140 P/31), Lusina (140P/39), Gródek nad Dunajcem (140 P/99),

Gródek nad Dunajcem (140 P/158).

Description: Verneuilinoides neocomiensis is typified by its large, massive and triserial test with globular chambers, increasing rapidly in dimensions; the periphery is rounded; the sutures are oblique and the wall is agglutinated.

Distribution: Upper Jurassic and Lower Cretaceous of the region of the Middle Volga River and the Great Syrte (Mjatliuk, 1939); Uppermost Tithonian-Lower Cretaceous (?) of the Eastern Indian Ocean (Kuznetsova, 1974); Upper Berriasian-Lower Aptian of Ain, Savoie, France (Darsac, 1983); Berriasian-Aptian of the Northern Atlantic and Indian Ocean (Riegraf and Luterbacher, 1989b); TithonianValanginian of Site 765, Northwestern Australia (Kaminski et al., 1992); Tithonian-Lower Aptian of the Barrow Group, Northwest shelf, Australia (Jones and Wonders, 1992); Tithonian-Early Valanginian of the southern part of the Crimea Mts., Southern Ukraine (Krajewski and Olszewska, 2007).

Known range: Uppermost Tithonian (Kuznetsova, 1974) Aptian (Riegraf and Luterbacher, 1989b; Jones and Wonders, 1992).

Verneuilinoides sp. P1. 1, Fig. 1

Material: Gródek nad Dunajcem (140 P/99).

Description: The observed section shows a large and massive test similar to $V$. neocomiensis but differs by its distinct triserial arrangement in the initial part, the flattened chambers and the rapid increase of the test width; the wall is agglutinated, exceptionally thick, solid, and coarse grained.

Suborder Nezzazatina KAMINSKI, 2004

Superfamily Nezzazatacea HAMAOUI \& SAINT-MARC, 1970

Family Nautiloculinidae LOEBLICH \& TAPPAN, 1985

Genus Nautiloculina MOHLER, 1938

Nautiloculina bronnimanni ARNAUD-VANNEAU \&

PEYBERNÉS, 1978. P1. 2, Figs. 2-4

1978 Nautiloculina bronnimanni ARNAUD-VANNEAU \& PEYBERNÉS, p. 70, P1. 1, Figs. 6-8; P1. 2, Figs. 4-11 (Synonymy). 
1983 Nautiloculina bronnimanni ARNAUD-VANNEAU \& PEYBERNÉS, Darsac p. 208, P1. 6, Figs. 26-27.

1989 Nautiloculina bronnimanni ARNAUD-VANNEAU \& PEYBERNÉS, Arnaud-Vanneau and Masse p. 264, Pl. 1, Fig. 9.

2003 Nautiloculina bronnimanni ARNAUD-VANNEAU \& PEYBERNĖS, Dragastan and Richter p. 93, P1. 1, Fig. 2; Pl. 9, Figs. 10, 11, 16.

2004 Nautiloculina broennimanni ARNAUD-VANNEAU \& PEYBERNĖS, Bucur et al., P1. 3, Fig. 22.

2004 Nautiloculina bronnimanni ARNAUD-VANNEAU \& PEYBERNĖS, Ivanova and Koleva-Rekalova, Pl. 1, Fig. 5. 2004 Nautiloculina bronnimanni ARNAUD-VANNEAU \& PEYBERNĖS, Ivanova and Kolodziej, Fig. 1 D.

2005 Nautiloculina cretacea PEYBERNES, Olszewska, p. 35, P1. 4, Fig. 3.

2007 Nautiloculina bronnimanni ARNAUD-VANNEAU \& PEYBERNĖS, Krajewski and Olszewska p. 297, Fig. 4 H.

Material: Jastrzębia (140 P/191); Lubenia (140P/11); Lusina (140P/52); Leńcze (140P/73), Gródek nad Dunajcem (140 P/158).

Description: Arnaud-Vanneau and Peybernés (1978) introduced the new species $N$. bronnimanni that is distinguished from $N$. cretacea by its smaller size, depressed sutures, and quadrangular chambers, which display a characteristic shape in the last world, and an acute periphery in axial section.

Distribution: Berriasian-Upper Albian of the French and Spanish Pyrenees (Arnaud-Vanneau and Peybernés, 1978); Berriasian-Lower Valanginian of Ain, Savoie, France (Darsac, 1983); Berriasian-Aptian of the Neuchatel area, Switzerland (Arnaud-Vanneau and Masse, 1989); Upper Berriasian-Lower Valanginian of the Mathana Peninsula, Asprovouni Mts., Greece (Dragastan and Richter, 2003); Valanginian-Hauterivian of the Berdiga Limestone, KaleGümüshane region, NE Turkey (Bucur et al., 2004); Berriasian-Valanginian of Southwestern Bulgaria (Ivanova and Koleva-Rekalova, 2004); Upper Berriasian-Valanginian of Stramberk-type limestones, Polish Carpathians (Ivanova and Kolodziej, 2004); Berriasian-Hauterivian of the Southern part of the Crimea Mts., Southern Ukraine (Krajewski and Olszewska, 2007).

Known range: Upper Tithonian (Bucur et al., 1996) Upper Albian (Arnaud-Vanneau and Peybernés, 1978).

Family Mayncinidae LOEBLICH \& TAPPAN, 1985

Genus Carasuella NEAGU, 2000

Carasuella sp. P1. 2, Fig. 5

Material: Gródek nad Dunajcem (140 P/91)

Description: The section shows the robust outline of the test, with a slightly lobate acute to rounded periphery, only the last 6 chambers are clearly visible; the section is similar to the species $C$. lenticularis, described from the Lower Valanginian of South Dobrogea by Neagu (1999).

Genus Freixialina RAMALHO, 1969

Freixialina planispiralis RAMALHO, 1969. Pl. 2, Fig. 1.

1969 Freixialina planispiralis, RAMALHO p. 37, Pl. 1-2.

1999 Freixialina planispira RAMALHO, Neagu p. 289,

Fig. 2 c-d; P1. 4, Figs. 1-15, 39-44; P1. 5, Figs. 55-64; P1. 9, Figs. 20-23.

2004 Freixialina planispiralis RAMALHO, Bucur et al., P1. 4, Figs. 10-12, 14.

2006 Freixialina planispiralis RAMALHO, Kobayashi and Vuks, Fig. 4, 5-10.

2008 Freixialina planispiralis RAMALHO, Omaña and González Arreola, p. 803, P1. 9 g.

Studia UBB, Geologia, 2010, 55 (2), 3 - 31
Material: Woźniki (140P/31)

Description: Freixialina planispiralis is characterized by its discoidal to lenticular shape test; evolute coiling, with up to 17 narrow chambers increasing rapidly in height, with weakly visible sutures in the last whorl; the wall is finely agglutinated, rather thin, and compact.

Distribution: Upper Jurassic of Portugal (Ramalho, 1969); Uppermost Berriasian-Lowermost Hauterivian of South Dobrogea (Neagu, 1999); Hauterivian-Barremian of the Berdiga Limestone, Kale-Gümüshane region, NE Turkey (Bucur et al., 2004); undivided Tithonian-Berriasian of Torinosu-type limestones, Kanto Mts., Japan (Kobayashi and Vuks, 2006); Kimmeridgian of Santiago Coatepec, SE Puebla, Mexico (Omaña and González Arreola, 2008).

Known range: Kimmeridgian (Omaña and González Arreola, 2008) - Barremian (Bucur et al., 2004).

Genus Mayncina NEUMANN, 1965

Mayncina cf. bulgarica LAUG, PEYBERNÉS \& REY, 1980. Pl. 2, Fig. 11.

*1980 Mayncina bulgarica LAUG, PEYBERNÉS \& REY p. 68, Figs. 3, 1-16.

1984 Mayncina bulgarica LAUG, PEYBERNÉS \& REY, Canerot, P1. 2, Fig. 3.

1984 Mayncina bulgarica LAUG, PEYBERNÉS \& REY, Peybernés et al., Pl. 1, Fig. 8.

1988 Mayncina bulgarica LAUG, PEYBERNÉS \& REY, Bucur, P1. 1, Fig. 14.

2002 Mayncina bulgarica LAUG, PEYBERNÉS \& REY, Voznesenskii et al., P1. 2, Fig. 25.

2006 Mayncina bulgarica LAUG, PEYBERNÉS \& REY, Husinec and Sokać, Fig. 7, P-R.

2007 Mayncina bulgarica LAUG, PEYBERNÉS \& REY, Krajewski and Olszewska, p. 297, Fig. 4 J, K.

Material: Lusina 140 P/39; Gródek nad Dunajcem (140 $\mathrm{P} / 118)$.

Description: Mayncina bulgarica is distinquished by its discoidal to lenticular shape test, with numerous broad and low chambers; coiling is planispiral and the operculinoid spire increases slowly in height, chambers arched toward the apertural face, the sutures slightly depressed; the wall is finely agglutinated and simple in structure.

Distribution: Lower Aptian of Bulgaria (Laug et al., 1980); Uppermost Berriasian-Lower Hauterivian of the Eastern Iberides, Spain (Canerot, 1984); Barremian of the Daia Mountains, Oranie, Algeria (Peybernés et al., 1984); Uppermost Berriasian of the Resita-Moldova Noua zone, Southern Carpathians, Romania (Bucur, 1988); Aptian of the southeastern part of the Lesser Caucasus (Voznesenskii et al., 2002); Upper Hauterivian-Lower Barremian of Mljet Island, Southern Croatia (Husinec and Sokać, 2006).

Known range: Upper Berriasian (Canérot, 1984; Bucur, 1988) - Aptian (Laug et al., 1980; Voznesenskii et al., 2002).

Order Loftusiida KAMINSKI \& MIKHALEVICH, 2004

Suborder Biokovinina MIKHALEVICH \& KAMINSKI, 2004

Superfamily Coscinophragmatacea THALMANN, 1951

Family Coscinophragmatidae THALMANN, 1951

Genus Coscinophragma THALMANN, 1951

Coscinophragma cribrosum (REUSS, 1854), Pl. 3, Figs. 1-4 *1846 Lichenopora cribrosa REUSS p. 46, P1. 14, Fig. 10; P1. 24, Figs. 3-5.

1988 Coscinophragma cribrosum REUSS, Bucur, P1. 1, Fig. 3. 1996 Coscinophragma aff. cribrosum REUSS, Bucur et al., Pl. 1, Figs. 1, 5; P1. 6, Figs. 1-3, 5. 
2005 Coscinophragma? aff. cribrosum (REUSS), Schlagintweit et al., p. 27, Fig. 8 a-b (Synonymy)

Material: Lusina (140P/39); Gródek nad Dunajcem (140 $\mathrm{P} / 115,140 \mathrm{P} / 176)$.

Description: The species has an initial coiled part, attached to the substrate, followed by a detached uniserial stage.

Remarks: For detailed description and analysis of generic position see Bucur et al. (1996) and Schlagintweit et al. (2005)

Distribution: Cretaceous of the Bohemian Massif (Reuss, 1846); Valanginian of the Resita-Moldova Noua zone, Southern Carpathians, Romania (Bucur, 1988); Upper Tithonian of the Madonie Mts., Italy (Bucur et al., 1996); Uppermost Tithonian-Lowermost Berriasian of the Plassen carbonate platform, Salzkammergut area (Schlagintweit et al., 2005).

Known range: Upper Tithonian (Bucur et al., 1996) Lower Aptian (Arnaud-Vanneau et al., 1987).

Superfamily Biokovinacea GUŠIĆ, 1977

Family Charentiidae LOEBLICH \& TAPPAN, 1985

Genus Charentia NEUMANN, 1965

Charentia cuvillieri NEUMANN, 1965. P1. 3, Figs. 5-10

*1965 Charentia cuvillieri NEUMANN, p. 63, Pl. 2, Figs. 6-12.

1968 Melatrokerion spiralis Gorbachik p. 6, P1. 1, Figs. 1-6. 1968 Tonasia evoluta GORBACHIK, p. 8, P1. 2, Figs. 1-5.

1983 Charentia cf. cuvillieri NEUMANN, Darsac p. 209, Pl. 6, Fig. 24.

1985 Charentia cuvillieri NEUMANN, Loeblich and Tappan, p. 98, P1. 3, Figs. 1-13.

1989 Charentia cuvillieri NEUMANN, Arnaud-Vanneau and Masse p. 262, P1. 1, Fig. 8 Synonymy).

1993 Melathrokerion spiralis GORBACHIK, Dulub and Zhabina, P1. 5, Fig. 1.

1993 Charentia evoluta (GORBACHIK), Dulub and Zhabina, Pl. 1, Fig. 2.

1999 Charentia cuvillieri NEUMANN, Ivanova, P1. 2, Fig. 11.

1999 Charentia evoluta (GORBACHIK), Neagu, p. 292, P1. 3, Figs. 24-29; Pl. 9, Figs. 25, 26.

1999 Charentia cuvillieri NEUMANN, Schlagintweit and Ebli, p. 398, P1. 5, Figs. 1-3 (Synonymy).

2001 Charentia evoluta GORBATCHIK, Olszewska and Wieczorek, Pl. 3, Figs. 1, 2.

2002 Melathrokerion spiralis GORBACHIK, Voznesenskii et al., P1. 1, Fig. 4.

2003 Charentia cuvillieri NEUMANN, Dragastan and Richter, p. 91, Pl. 9, Fig. 9.

2004 Charentia cuvillieri NEUMANN, Bucur et al., p. 210, P1. 3, Fig. 22.

2004 Charentia cuvillieri NEUMANN, Ivanova and Koleva-Rekalova, P1. 2, Figs. 1-3.

2004 Charentia cuvillieri NEUMANN, Ivanova and

Kolodziej, Fig. 1 A.

2005 Charentia evoluta GORBACHIK, Olszewska, p. 35, P1. 4, Figs. 7, 8.

2006 Melatrokerion spiralis GORBACHIK, Arkad'ev et al., P1. 4, Figs. 8-10.

2006 Charentia evoluta GORBACHIK, Arkad'ev et al., Pl. 4, Fig. 15.

2006 Charentia evoluta GORBACHIK, Kobayashi and Vuks, Figs. 4 (27-32).

2006 Melatrokerion spiralis GORBACHIK, Kobayashi and Vuks, Fig. 4 (35-45).
2007 Charentia evoluta GORBACHIK, Krajewski and Olszewska, p. 299, Figs. 5 G, H.

2007 Melatrokerion spiralis GORBACHIK, Krajewski and Olszewska, p. 299, Fig. 5 I.

2008 Charentia cuvillieri NEUMANN, Ivanova et al., Fig. 7 $\mathrm{G}, \mathrm{H}$.

Material: Leńcze (140 P/45, 140 P/83); Gródek nad Dunajcem (140 P/84, 140 P/99, 140 P/105); Lusina, UJ $140 \mathrm{P} / 39$.

Description: Charentia cuvillieri is characterized by its planispirall enrollment in the early stage test with a clearly tendency to uncoil in the last stage where two chambers are present; periphery is subacute to round.

Remarks: Loeblich and Tappan (1985) described in details the nature of the wall; for synonyms at species and genera level see Loeblich and Tappan (1985), Neagu (1999) and Bucur et al. (2004).

Distribution: Cenomanian of Charente Maritime, France (Neumann, 1965); Berriasian and Valanginian of the Crimea (Gorbachik, 1968); Berriasian-Lower Valanginian of Ain, Savoie, France (Darsac, 1983); Cenomanian of the Charente Maritime, France (Loeblich and Tappan, 1985); Middle Berriasian-Cenomanian of the Neuchatel area, Switzerland (Arnaud-Vanneau and Masse, 1989); undivided Tithonian and Berriasian of the South-Eastern Crimea (Dulub and Zhabina, 1993); Berriasian-Valanginian of West Balkan Mts., Bulgaria (Ivanova, 1999); Uppermost BerriasianLower Hauterivian of South Dobrogea, Romania (Neagu, 1999); Upper Tithonian-Lower Valanginian of the Trisselwand section, Northern Calcareous Alps (Schlagintweit and Ebli, 1999); Upper Tithonian of Andrychow Klippe, Outer Western Carpathians, Poland (Olszewska and Wieczorek, 2001); Upper Tithonian of Southeastern part of the Lesser Caucasus (Voznesenskii et al., 2002); Lower Valanginian of the Mathana Peninsula, Asprovouni Mts., Greece (Dragastan and Richter, 2003); Valanginian-Barremian of the Berdiga Limestone, KaleGümüshane region, NE Turkey (Bucur et al., 2004); Berriasian-Valanginian of Southwestern Bulgaria (Ivanova and Koleva-Rekalova, 2004); Upper Berriasian-Valanginian of the Stramberk-type limestones (Ivanova and Kolodziej, 2004); Berriasian-Valanginian of Cieszyn Beds, Polish Outer Carpathians (Olszewska, 2005); Upper Tithonian of the Eastren Crimea (Arkad'ev et al., 2006); undivided Tithonian-Berriasian of Torinosu-type limestones, Kanto Mts., Japan (Kobayashi and Vuks, 2006); BerriasianValanginian of Southwestern Bulgaria (Ivanova et al., 2008).

Known range: Upper Tithonian (Bucur et al., 1996) Cenomanian (Neumann, 1965; Loeblich and Tappan, 1985). Genus Melathrokerion BRÖNNIMANN \& CONRAD, 1967 Melathrokerion valserinensis BRÖNNIMANN \& CONRAD, 1967. P1. 2, Figs. 12-15 1967 Melathrokerion valserinensis BRÖNNIMANN \& CONRAD, p. 137, Pl. 1-3, 11, and figures in the text. 1983 Melathrokerion cf. valserinensis BRÖNNIMANN \& CONRAD, Darsac, p. 212, P1. 7, Figs. 2, 3. 1989 Melathrokerion valserinensis BRÖNNIMANN \& CONRAD, Arnaud-Vanneau and Masse, p. 262, P1. 1, Fig. 6. 1995 Melathrokerion sp. cf. M. valserinensis BRÖNNIMANN \& CONRAD, Arnaud-Vanneau and Sliter, p. 550, P1. 1, Figs. 3, 4.

Material: Gródek nad Dunajcem (140 P/78, 140 P/100); Woźniki (140 P/23; 140 P/177). 
Description: This species is distinguished by its nautiloid, planispirally coiled and involute test, with a slight tendency to be streptospiral in the early stage; few chambers per whorl as in Charentia and a broadly rounded periphery; the wall is agglutinated, microgranular, thick, simple in the early stage, later becoming pseudoalveolar with very narrow cylindrical canaliculi piercing the wall but not becoming true alveoles (note pseudoalveolar structure in P1. 2, Figs. 12, 13, and 15).

Distribution: Upper Barremian-Lowermost Aptian of the French Jura (Brönnimann \& Conrad, 1967); Middle-Upper Berriasian of Ain, Savoie, France (Darsac, 1983); Barremian of Neuchatel area, Switzerland (Arnaud-Vanneau and Masse, 1989); Probable Hauterivian of the Mid-Pacific Mts. (Arnaud-Vanneau and Sliter, 1995).

Known range: Berriasian (Darsac, 1983) - Lowermost Aptian (Brönnimann and Conrad, 1967).

Suborder Ataxophragmiina FURSENKO, 1958

Superfamily Ataxophragmiacea SCHWAGER, 1877

Family Ataxophragmiidae SCHWAGER, 1877

Subfamily Ataxophragmiinae SCHWAGER, 1877

Genus Arenobulimina CUSHMAN, 1927

Arenobulimina sp. P1. 1, Fig. 16

Material: Woźniki (UJ 140P/31).

Description: The observed specimen possesses a trochospiral test, with the early part trochospirally enrolled; chambers in the last part of the test are globulus with depressed sutures; the wall is finely agglutinated and the section is similar to A. corniculum Arnaud-Vanneau (1980) figured by Darsac (1983; P1. 5, Figs. 32, 33) and later by Neagu (1997; P1. 2, Figs. 56-58; P1. 4, Figs. 20-26).

Family Montsaleviidae (ZANINETTI, SALVINIBON-

NARD, CHAROLLAIS \& DECROUEZ, 1987)

Genus Montsalevia (ZANINETTI, SALVINI-BONNARD, CHAROLLAIS \& DECROUEZ, 1987)

Montsalevia salevensis (CHAROLLAIS, BRÖNNIMANN \& ZANINETTI, 1966). P1. 2, Fig. 10

1966 Pseudotextulariella salevensis CHAROLLAIS, BRÖNNIMANN \& ZANINETTI, p. 28, P1. 1, Figs. 1-5; P1.

2, Figs. 2, 6; text-fig. 1.

1983 Pseudotextulariella salevensis CHAROLLAIS,

BRÖNNIMANN \& ZANINETTI, Darsac p. 214, P1. 5,

Figs. 9-13 (Synonymy).

1995 Montsalevia salevensis CHAROLLAIS,

BRÖNNIMANN \& ZANINETTI, Bucur et al., Pl. 4,

Figs. 11-15.

1999 Montsalevia salevensis CHAROLLAIS,

BRÖNNIMANN \& ZANINETTI, Ivanova, Pl. 1, Fig. 11

(non: Fig. 12).

2002 Pseudotextulariella salevensis CHAROLLAIS,

BRÖNNIMANN \& ZANINETTI, Voznesenskii et al., P1. 1, Fig. 28.

2004 Montsalevia salevensis CHAROLLAIS,

BRÖNNIMANN \& ZANINETTI, Bucur et al., P1. 3,

Figs. 1-5.

2004 Montsalevia salevensis CHAROLLAIS,

BRÖNNIMANN \& ZANINETTI, Ivanova and Koleva-

Rekalova, P1. 2, Figs. 4-6.

2004 Montsalevia salevensis CHAROLLAIS,

BRÖNNIMANN \& ZANINETTI, Ivanova and Kolodziej,

Fig. $1 \mathrm{~K}$.

2005 Montsalevia salevensis CHAROLLAIS,

BRÖNNIMANN \& ZANINETTI, Bucur and Săsăran, P1. 4,

Figs. 3-8.

Studia UBB, Geologia, 2010, 55 (2), 3 - 31
2006 Montsalevia salevensis CHAROLLAIS,

BRÖNNIMANN \& ZANINETTI, Husinec and Sokać,

Fig. 7 D, F-H.

2007 Montsalevia salevensis CHAROLLAIS,

BRÖNNIMANN \& ZANINETTI, Bruni et al., Pl. 3, Figs. 1, 2

non 2007 Montsalevia salevensis CHAROLLAIS, BRÖNNIMANN \& ZANINETTI, Krajewski and Olszewska, Fig. $5 \mathrm{~K}$.

Material: Jastrzębia (140 P/191); Lusina (140P/41)

Description: Montsalevia salevensis is characterized by a reduced conical test with trochospiral initial portion, followed by a biserial portion composed of 5 to 8 sets of chambers that are wider than high, periphery subangular to rounded; the wall is calcareous, microgranular, simple, and imperforate.

Distribution: Upper Valanginian of the Haute-Savoie, France (Charollais et al., 1966); Valanginian of Ain, Savoie, France (Darsac, 1983); Valanginian of the Jerma River canyon, Eastern Serbia (Bucur et al., 1995); Valanginian of the West Balkan Mts., Bulgaria (Ivanova, 1999); Valanginian of the southeastern part of the Lesser Caucasus (Voznesenskii et al., 2002); Berriasian- Hauterivian of the Berdiga Limestones, Kale-Gümüshane region, NE Turkey (Bucur et al., 2004); Valanginian of Southwestern Bulgaria (Ivanova and Koleva-Rekalova, 2004); Upper BerriasianValanginian of Stramberk-type limestones, Polish Carpathians (Ivanova and Kolodziej, 2004); Lower Valanginian of the Apuseni Mountains, Romania (Bucur and Săsăran, 2005); Valanginian of Mljet Island, Southern Croatia (Husinec and Sokać, 2006); undivided BerriasianValanginian of Fara San Martino, Maiella, Italy (Bruni et al., 2007).

Known range: Upper Berriasian (Bucur et al., 2004; Ivanova and Kolodziej, 2004) - Hauterivian (Bucur, 1988).

Suborder Orbitolinina KAMINSKI, 2004

Superfamily Pfenderinacea SMOUT \& SUGDEN, 1962

Family Pfenderinidae SMOUT \& SUGDEN, 1962

Subfamily Pseudopfenderininae SEPTFONTAINE, 1988

Genus Siphovalvulina SEPTFONTAINE, 1988

Siphovalvulina variabilis SEPTFONTAINE, 1988. Pl. 1, Fig. 19.

1980 Siphovalvulina sp., SEPTFONTAINE, P1. 2, Fig. 10; Pl. 3, Figs. 17, 18.

1983 Belorussiella sp., Darsac p. 211, P1. 7, Figs. 18, 19.

*1988 Siphovalvulina variabilis, SEPTFONTAINE, p. 245, Fig. 5.

2004 Siphovalvulina variabilis SEPTFONTAINE, Ivanova and Koleva-Rekalova, P1. 3, Fig. 8.

2005 Siphovalvulina variabilis SEPTFONTAINE,

Schlagintweit et al. p. 42, P1. 26 a-c (Synonymy).

2005 Belorussiella cf. taurica GORBATCHIK, Olszewska p. 34, Pl. 4, Fig. 15.

2005b Siphovalvulina variabilis SEPTFONTAINE,

Gutowski et al., Fig. 10, A.

2006 Siphovalvulina sp., Kobayshi and Vuks, P1. 6 (1, 3, 4, $5)$.

2007 Siphovalvulina variabilis SEPTFONTAINE,

Krajewski and Olszewska, p. 301, Fig. 6 A.

2008 Siphovalvulina variabilis SEPTFONTAINE, Ivanova et al., Fig. 6, R.

Material: Woźniki (140P/31); Lusina (140P/39).

Description: The species is characterized by the trochospirally-coiled test with three subglobular chambers per whorl, which are increasing in size in growth direction, 
and a twisted siphonal canal connecting successive apertures.

Remarks: This common form has been variously placed in Belorussiella, Trochammina, or Gaudryina, but these genera do not possess a central siphon; for details see Septfontaine (1980, 1988) and Loeblich and Tappan (1987).

Distribution: Domerian of Morocco; Bathonian of France and Callovian of the Swiss Prealps (Septfontaine, 1980); Upper Berriasian of Ain, Savoie, France (Darsac, 1983); Hettangian to Lower (?Upper) Cretaceous of the Swiss Prealps (Septfontaine, 1988); Upper KimmeridgianValanginian of Southwestern Bulgaria (Ivanova and KolevaRekalova, 2004); Uppermost Kimmeridgian-Upper Tithonian of the Plassen carbonate platform, Northern the Calcareous Alps (Schlagintweit et al., 2005); Upper Tithonian-Middle Berriasian of Cieszyn Beds, Polish Outer Carpathians (Olszewska, 2005); Upper Tithonian-Lower Berriasian of the Nizniow area, Western Ukraine (Gutowski et al., 2005b); Middle Jurassic-Tithonian of the Southern part of the Crimea Mts., Southern Ukraine (Krajewski and Olszewska, 2007); Upper Kimmeridgian-Lower Berriasian of Southwestern Bulgaria (Ivanova et al., 2008).

Known range: Hettangian-Upper Barremian to ?Upper Cretaceous (Septfontaine, 1988).

Subfamily PFENDERININAE SMOUT \& SUGDEN, 1962 Genus Dobrogelina NEAGU, 1979

Dobrogelina ovidi NEAGU, 1979. P1. 2, Figs. 16-19

*1979 Dobrogelina ovidi, NEAGU, p. 494, P1. 1, Figs. 1-7; P1. 4, Figs. 17-18.

1983 Dobrogelina ovidi ? NEAGU, Darsac, p. 211, P1. 7, Figs. 13-15.

2004 Dobrogelina ovidi NEAGU, Ivanova and KolevaRekalova, P1. 3, Figs. 9, 11.

2007 Dobrogelina ovidi NEAGU, Krajewski and Olszewska, p. 301, Fig. 6 B.

2008 Dobrogelina sp., Ivanova et al., Fig. 7, J.

Material: Woźniki (140P/31); Lusina (140P/39); Gródek nad Dunajcem (140 P/100, 140 P/110).

Description: Dobrogelina ovidi is characterized by its trochospirally enrolled test, with a nearly flat to moderately conical spire. The trochospire has six to twelve chambers in the final whorl; the wall is thin, consisting of nonlamellar, microgranular calcite.

Distribution: Upper Berriasian of the southern part of Dobrogea, Romania (Neagu, 1979); Berriasian-Lower Valanginian of Ain, Savoie, France (Darsac, 1983); Berriasian-Valanginian of Southwestern Bulgaria (Ivanova and Koleva-Rekalova, 2004); Berriasian-Valanginian of the Southern part of the Crimea Mts., Southern Ukraine (Krajewski and Olszewska, 2007); Berriasian-Valanginian of Southwestern Bulgaria (Ivanova et al., 2008).

Known range: Berriasian (Darsac, 1983; Ivanova and Koleva-Rekalova, 2004) - Valanginian (Darsac, 1983; Ivanova et al., 2008).

Family Hauraniidae SEPTFONTAINE, 1988

Subfamily Amijellinae SEPTFONTAINE, 1988

Genus Pseudocyclammina YABE \& HANZAWA, 1926

Pseudocyclammina lituus (YOKOYAMA, 1890). P1. 4, Figs. 1-10

*1890 Cyclammina lituus, YOKOYAMA, p. 26, P1. 5, Fig. 7. 1983 Pseudocyclammina lituus YOKOYAMA, Darsac, p. 213 , P1. 8, Figs. 6-8.

1995 Pseudocyclammina lituus YOKOYAMA, Bucur et al., P1. 1, Figs. 3, 4.
1999 Pseudocyclammina lituus YOKOYAMA, Ivanova, P1. 1, Fig. 6.

2001 Pseudocyclammina lituus YOKOYMA, Olszewska and Wieczorek, P1. 4, Figs. 5.

2002 Pseudocyclammina lituus YOKOYAMA,

Voznesenskii et al., P1. 1, Fig. 20.

2003 Pseudocyclammina lituus (YOKOYAMA) YABE \& HANZAWA, Dragastan and Richter p. 92, P1. 9, Figs. 1-2; P1. 12, Fig. 1.

2004 Pseudocyclammina lituus YOKOYAMA, Bucur et al., P1. 4, Figs. 1, 2, 5.

2004 Pseudocyclammina lituus YOKOYAMA, Ivanova and Koleva-Rekalova, P1. 1, Fig. 10.

2004 Pseudocyclammina lituus YOKOYAMA, Ivanova and Kolodziej, Fig. 1 B.

2005 Pseudocyclammina lituus YOKOYMA, Olszewska p. 35, P1. 4, Fig. 10.

2005 Pseudocyclammina lituus (YOKOYMA),

Schlagintweit et al. p. 38, Pl. 22 a-d (Synonymy).

2006 Pseudocyclammina lituus YOKOYMA, Arkad'ev et al., P1. 4, Fig. 14.

2006 Pseudocyclammina lituus YOKOYMA, Kobayashi and Vuks, Pl. 5, Figs. 7-14.

2007 Pseudocyclammina lituus YOKOYMA, Krajewski and Olszewska p. 301, Fig. 6, F.

2008 Pseudocyclammina lituus YOKOYAMA, Ivanova et al., Fig. 7 A.

Material: Leńcze (140 P/45, 140 P/83); Lusina (140P/52); Woźniki (140 P/177); Gródek nad Dunajcem (140 P/99; 140 $\mathrm{P} / 105,140 \mathrm{P} / 180)$; Zamarski (140P/36); Jastrzębia (140 $\mathrm{P} / 191)$; Gródek nad Dunajcem (140 P/158)

Description: The test is planispirally-enrolled, subspherical to flattened, involute at least in the early stage, later uncoiling, and sutures strongly oblique in the coiled stage; the wall is coarsely agglutinated, with coarse subepidermal network; the exoskeleton may have a few irregular pillars in a narrow zone in the median plane of the test, the endoskeleton consisting of thick and massive septa, perforated by large openings.

Distribution: Berriasian-Lower Valanginian of Ain, Savoie, France (Darsac, 1983); Valanginian of the Jerma River canyon, Eastern Serbia (Bucur et al., 1995); Upper KimmeridgianBerriasian of the West Balkan Mts., Bulgaria (Ivanova, 1999); Oxfordian-Berriasian of Cieszyn Beds, Polish Outer Carpathians (Olszewska, 2005); Upper Tithonian Plassen carbonate platform, Northern Calcareous Alps (Schlagintweit et al., 2005); Upper Tithonian of the eastern Crimea (Arkad'ev et al., 2006); undivided Tithonian-Berriasian of Torinosu-type limestones, Kanto Mts., Japan (Kobayashi and Vuks, 2006); Oxfordian-Berriasian of the southern part of the Crimea Mts., Southern Ukraine (Krajewski and Olszewska, 2007); Upper Kimmeridgian - Valanginian of Southwestern Bulgaria (Ivanova et al., 2008).

Known range: Oxfordian (Hughes, 2004; Velić, 2007) Hauterivian (Canérot, 1984).

Order Textulariida DELAGE \& HEROUARD, 1896

Suborder Textulariina DELAGE \& HEROUARD, 1896

Superfamily Chrysalidinacea NEAGU, 1968

Family Paravalvulinidae BANNER, SIMMONS \&

WHITTAKER, 1991

Subfamily Paravalvulininae BANNER, SIMMONS \&

WHITTAKER, 1991

Genus Redmondoides BANNER, SIMMONS \&

WHITTAKER, 1991

Studia UBB, Geologia, 2010, 55 (2), 3 - 31 
Redmondoides lugeoni (SEPTFONTAINE, 1977), P1. 1,

Figs. 6-8

1977 Valvulina lugeoni, SEPTFONTAINE, p. 612, P1. 2,

Fig. 2-5; text Fig. 6.

1987 Valvulina aff. lugeoni SEPTFONTAINE, Sotak, P1. 4,

Figs. 4-5.

2004 Valvulina lugeoni SEPTFONTAINE, Ivanova and Kolodziej, Fig. 1 E.

2005 Redmondoides cf. lugeoni SEPTFONTAINE, Schlagintweit et al. p. 40, P1. 25 a-d (Synonymy).

2006 Valvulina spp., Kobayashi and Vuks, Fig. 6 (12).

2008 Valvulina lugeoni SEPTFONTAINE, Ivanova et al., Fig. $6 \mathrm{H}$.

Material: Woźniki (140 P/31); Gródek nad Dunajcem (140 $\mathrm{P} / 78$ ).

Description: The species is characterised by its trochospiral and triserial test with valvular tooth plate simple or perforate by supplementary apertures (pores); primary aperture is a basal slit.

Distribution: Dogger-Lower Malm? (Septfontaine, 1977); Lower-Middle Berriasian of the Stramberk carbonate platform, Outer Western Carpathians, Slovakia (Sotak, 1987); Upper Berriasian-Valanginian of Stramberk-type limestones, Polish Carpathians (Ivanova and Kolodziej, 2004); Uppermost Kimmeridgian-Tithonian Plassen carbonate platform, Northern Calcareous Alps (Schlagintweit et al., 2005); Upper Kimmeridgian-Lower Berriasian of Southwestern Bulgaria (Ivanova et al., 2008).

Known range: Lias? Bajocian (Septfontaine, 1977) Valanginian (Ivanova and Kolodziej, 2004).

Order Spirillinida GORBACHIK \& MANTSUROVA, 1980

Suborder Involutinina HOHENEGGER \& PILLER, 1977

Family Ventrolaminidae WEYNSCHENK, 1950

Genus Protopeneroplis WEYNSCHENK, 1950

Protopeneroplis striata WEYNSCHENK, 1950. P1. 5, Fig. 7 1950 Protopeneroplis striata WEYNSCHENK, p. 13, Fig. 2.

1987 Protopeneroplis striata WEYNSCHENK, Sotak, P1. 3, Fig. 10, 11-12.

1997 Protopeneroplis striata WEYNSCHENK, Bucur, p. 65, P1. 1, Figs. 1-12 (Synonymy)

2001 Protopeneroplis striata WEYNSCHENK, Olszewska and Wieczorek, Pl. 4, Fig. 7.

2004 Protopeneroplis striata WEYNSCHENK, Bucur et al., Pl. 1, Figs. 3, 4.

2005 Protopeneroplis striata WEYNSCHENK,

Schlagintweit et al. p. 36, P1. 20: a-c (Synonymy)

?2005 Protopeneroplis striata WEYNSCHENK,

Olszewska, P1. 5, Fig. 13.

2005 Protopeneroplis striata WEYNSCHENK, Bucur and

Săsăran, P1. 2, Figs. 2, 10.

2006 Protopeneroplis striata WEYNSCHENK, Arkad'ev et al., P1. 4, Fig. 2.

2007 Protopeneroplis striata WEYNSCHENK, Krajewski and Olszewska, p. 303, Fig. 8 D, E.

2008 Protopeneroplis striata WEYNSCHENK, Ivanova et al., Fig. 6 J, K.

Material: Zamarski (UJ 140P/36).

Description: Protopeneroplis striata has a lenticular shape test, consisting of rapidly enlarging, planispirally to low trochospirally coiled, numerous chambers arranged in two whorls; coiling is involute; the wall consists of two layers (inner and outer layers are microgranular and hyaline calcareous, respectively); septa separating the chambers are made up of both microgranular and hyaline carbonate; aperture is areal.

Distribution: Middle/Upper Dogger and Malm of Sonnwend Mountain, Tyrol, Austria (Weynschenk, 1950); Outer Western Carpathians, Slovakia (Sotak, 1987); Oxfordian to Tithonian, Romania (Bucur, 1997); Upper Tithonian of the Andrychow Klippes, Outer Western Carpathians, Poland (Olszewska and Wieczorek, 2001); Oxfordian of the Berdiga Limestone, KaleGümüshane region, NE Turkey (Bucur et al., 2004); Kimmeridgian-Lower Tithonian Plassen carbonate platform, Northern Calcareous Alps (Schlagintweit et al., 2005); Upper Oxfordian-Lower Tithonian of the Apuseni Mountains, Romania (Bucur and Săsăran, 2005); Lower Tithonian of the eastern Crimea (Arkad'ev et al., 2006); Middle-Late Jurassic (up to Tithonian) of the southern part of the Crimea Mts., Southern Ukraine (Krajewski and Olszewska, 2007); Oxfordian-Lower Tithonian of Southwestern Bulgaria (Ivanova et al., 2008).

Discussion: Bucur et al. (1993) determined the range of the species as reaching Upper Tithonian-Berriasian. Later, Bucur et al. (2004) mentioned, that the presence of the species in sediments belonging to Berriasian age is uncertain.

Known range: Aalenian (Septfontaine, 1974) - Upper Tithonian (Schlagintweit and Ebli, 1999; Bucur et al., 2004). Protopeneroplis ultragranulata (GORBACHIK, 1971), P1. 5, Figs. 1-6.

*1971 Hoeglundina (?) ultragranulata, GORBACHIK, P1. 5, Fig. 2 a-c.

1987 Protopeneroplis trochangulata SEPTFONTAINE, Sotak, p. 653, Pl. 2, Figs. 1-9; P1. 3, Figs. 1-9 Synonymy). 1993 Protopeneroplis ultragranulata (GORBACHIK), Bucur, p. 214, Pl. 2, Figs. 1, 2, 5, 8, 11, 12 (Synonymy). 1997 Protopeneroplis ultragranulata (GORBACHIK), Bucur, p. 67, P1. 1, Figs. 13-16; P1. 2, Figs. 1-14; P1. 3, Figs. 1-3 (Synonymy).

2004 Protopeneroplis trochangulata SEPTFONTAINE, Ivanova and Kolodziej, Fig. $1 \mathrm{C}$.

2005 Protopeneroplis ultragranulata GORBATCHIK, Schlagintweit et al., p. 37, P1. 21 a-d (Synonymy).

2005 Protopeneroplis ultragranulata GORBACHIK, Olszewska p. 37, Pl. 5, Figs. 15, 16.

2005 Protopeneroplis ultragranulata (GORBACHIK), Bucur and Săsăran, P1. 4, Figs. 10, 11.

2006 Protopeneroplis ultragranulata GORBACHIK,

Arkad'ev et al., P1. 4, Figs. 18, 19 a, b, c.

2007 Protopeneroplis ultragranulata GORBACHIK, Bruni et al., P1. 3, Figs. 5, 6.

2007 Protopeneroplis ultragranulata (GORBACHIK), Velić, P1. 11, Figs. 1-5.

2007 Protopeneroplis ultragranulata (GORBACHIK), Krajewski and Olszewska, p. 303, Fig. 7 C.

2008 Protopeneroplis trochangulata SEPTFONTAINE, Ivanova et al., Fig. 7 E, F.

Material: Woźniki 140 P/23, 140P/31); Lubenia (140 P/11); Lusina (140P/52); Gródek nad Dunajcem (140 P/79, 140 $\mathrm{P} / 90,140 \mathrm{P} / 97,140 \mathrm{P} / 99)$.

Description: Protopeneroplis ultragranulata (Gorbatchik) differs from $P$. striata Weynschenk by its trochospiral test with angular periphery, larger dimensions and a pustulated ornamentation on the spiral face.

Remarks: Septfontaine (1974) provided a detailed description of this species (sub Protopeneroplis trochangulata); for a complete description and synonymy 
see also Soták (1987), Bucur (1993, 1997), and Schlagintweit et al. (2005).

Distribution: Upper Tithonian-Berriasian of the Crimea, Russia (Gorbachik, 1971); Lower-Middle Berriasian of the Stramberk platform, Outer Western Carpathians, Slovakia (Sotak, 1987); Upper Tithonian-Barremian of Romania (Bucur, 1993, 1997); Upper Berriasian-Valanginian of the Stramberk-type limestones (Ivanova and Kolodziej, 2004); Upper Tithonian of the Plassen carbonate platform, Northern Calcareous Alps (Schlagintweit et al., 2005); Middle part of Upper Tithonian-Valanginian of the Cieszyn Beds, Polish Outer Carpathians (Olszewska, 2005); Upper Tithonian-Valanginian of the Apuseni Mts., Romania (Bucur and Săsăran, 2005); Upper Tithonian of the eastern Crimea (Arkad'ev et al., 2006); undivided BerriasianValanginian of Fara San Martino, Maiella, Italy (Bruni et al., 2007); Upper Tithonian-Berriasian of the Karst Dinarides, SE Europe (Velić, 2007); Upper TithonianValanginian of the southern part of the Crimea Mts., Southern Ukraine (Krajewski and Olszewska, 2007); Berriasian-Valanginian of Southwestern Bulgaria (Ivanova et al., 2008).

Discussion: According Heinz and Isenschmid (1988) in the "Nappe des Prealpes medians", Switzerland the species $P r$. trochangulata (Pr. ultragranulata) appear in resediments of Albeuve strata, i.e. just before the appearance of the first Calpionellids. This coeval arise of the both species is important evidence for the first appearance of the species Pr. ultragranulata in the late Tithonian.

Known range: Upper Tithonian (Gorbachik, 1971; Bucur, 1997 e.c.) - Valanginian/Barremian (Bucur, 1997).

Suborder Spirillinina HOHENEGGER \& PILLER, 1975

Family Spirillinidae REUSS \& FRITSCH, 1861

Genus Spirillina EHRENBERG, 1843

Spirillina sp. P1. 2, Fig. 21

Material: Woźniki (140 P/23).

Description: The section is round and possesses a proloculus followed by a nonseptate, planispirally enrolled tubular second chamber; the aperture is not visible; the illustrated specimen is similar to $S$. italica Dieni and Massari, 1966 figured by Bucur, 1988 (Pl. 2, Figs. 29, 30).

Family Patellinidae RHUMBLER, 1906

Subfamily Patellininae RHUMBLER, 1906

Genus Patellina WILLIAMSON, 1858

Patellina turriculata DIENI \& MASSARI, 1966. P1. 5, Figs. 8-11.

*1966 Patellina turriculata, DIENI \& MASSARI, p. 222, P1. 8, Figs. 15, 16.

1988 Patellina turriculata DIENI \& MASSARI, Bucur, 382.

1991 Patellina sp., Altiner, P1. 10, Figs. 31-33.

1991 Patellina turriculata DIENI \& MASSARI, Altiner, P1. 13, Fig. 24.

1999 Patellina turriculata DIENI \& MASSARI, Ivanova, P1. 1, Fig. 13.

2004 Patellina turriculata DIENI \& MASSARI, Ivanova and Kolodziej, Fig. 1 F-H.

2008 Patellina turriculata DIENI \& MASSARI, Ivanova et al., Fig. 7 M.

Material: Lusina (140P/39); Woźniki (140P/31).

Description: Patellina turriculata is characterised by its low conical, planoconvex test formed by a proloculus followed by an undivided coiled tubular chamber arranged in one to three whorls; the test has a flattened umbilical side and carinate periphery.

Distribution: Upper Valanginian of northeastern Sardinia, Italy (Dieni and Massari, 1966); Upper Berriasian-Lower Hauterivian of the Resita-Moldova Noua zone, Southern Carpathians, Romania (Bucur, 1988); ValanginianBarremian of northwestern Anatolia, Turkey (Altiner, 1991); Upper Valanginian-Lower Hauterivian of the West Balkan Mts., Bulgaria (Ivanova, 1999); Valanginian of the Stramberk-type limestones (Ivanova and Kolodziej, 2004); Valanginian of southwestern Bulgaria (Ivanova et al., 2008). Known range: Upper Berriasian (Bucur, 1988) - Barremian (Altiner, 1991).

Order Miliolida LANKESTER, 1885

Suborder Miliolina DELAGE \& HEROUARD, 1896

Superfamily Cornuspiracea SCHULTZE, 1854

Family Cornuspiridae SCHULTZE, 1854

Subfamily Meandrospirinae SAIDOVA, 1981

Genus Meandrospira LOEBLICH \& TAPPAN, 1946

Meandrospira favrei (CHAROLLAIS, BRÖNNIMANN \& ZANINETTI, 1966). P1. 2, Figs. 8, 9

*1966 Citaella? Favrei, CHAROLLAIS, BRÖNNIMANN

\& ZANINETTI, p. 37, Pl. 2, Figs. 3, 4; P1. 3, Figs. 1-5; P1.

5, Figs. 1, 2; Text-Figs. 4-6.

1999 Meandrospira favrei CHARROLAIS, BROENNIMANN \& ZANINETTI, Ivanova, P1. 1, Figs. 9, 10.

1999 Meandrospira favrei CHARROLAIS,

BROENNIMANN \& ZANINETTI, Schlagintweit and Ebli, p. 398, P1. 4, Figs. 8, 11 (Synonymy).

2004 Meandrospira favrei CHARROLAIS,

BROENNIMANN \& ZANINETTI, Bucur et al., P1. 2,

Figs. 18-23.

2004 Meandrospira favrei CHARROLAIS,

BROENNIMANN \& ZANINETTI, Ivanova and Kolodziej,

Fig. $1 \mathrm{~L}, \mathrm{M}$.

non 2007 Meandrospira favrei CHARROLAIS,

BROENNIMANN \& ZANINETTI, Krajewski and

Olszewska, Fig. 7 B.

2008 Meandrospira favrei CHARROLAIS, BROENNIMANN \& ZANINETTI, Ivanova et al., Fig. 7, N, O.

Material: Woźniki (140P/31); Lusina (140P/39).

Description: The test of the species $M$. favrei is very small; the proloculus is followed by a spirally enrolled tubular undivided second chamber, bending back and forth in involute zigzag bends that enroll planispirally at the umbilicus; the wall is thin, calcareous, porcelaneous.

Distribution: Upper Valanginian-Upper Hauterivian of Haute-Savoie, France (Charrolais et al., 1966); Upper Valanginian- Lower Hauterivian of the West Balkan Mts., Bulgaria (Ivanova, 1999); Valanginian of the Trisselwand section, Northern Calcareous Alps (Schlagintweit and Ebli, 1999); Valanginian-Hauterivian of the Berdiga Limestones, Kale-Gümüshane region, NE Turkey (Bucur et al., 2004); Valanginian of the Stramberk-type limestones (Ivanova and Kolodziej, 2004); Valanginian of southwestern Bulgaria (Ivanova et al., 2008).

Known range: Valanginian (Schlagintweit and Ebli, 1999; Bucur et al., 2004; Ivanova and Kolodziej, 2004; Ivanova et al., 2008) - Lower Aptian (Neagu, 1970a).

Superfamily Nubeculariacea JONES, 1875

Family Nubeculariidae JONES, 1875

Subfamily Nubeculinellinae AVNIMELECH \& REISS, 1954

Genus Hechtina BARTENSTEIN \& BRAND, 1949 
Hechtina praeantiqua BARTENSTEIN \& BRAND, 1949.

Plate 2, Fig. 7.

*1949 Hechtina praeantiqua, BARTENSTEIN \& BRAND p. 669, Fig. 1 a-c; 2 a-c.

1949 Hechtina antiqua (REUSS), Bartenstein \& Brand p. 670, Fig. 10 a-b.

1970b Hechtina antiqua (REUSS), Neagu p. 420, P1. 1-3, Figs. 1-41, Text-Figs. 1-3.

1983 Hechtina praeantiqua BARTENSTEIN \& BRAND, Darsac p. 216, Pl. 6, Figs. 15-17.

1991 Hechtina praeantiqua BARTENSTEIN \& BRAND, Altiner, Pl. 10, Figs. 9-13.

1999 Hechtina praeantiqua BARTENSTEIN \& BRAND, Ivanova, Pl. 1, Fig. 14.

2005 Hechtina praeantiqua BARTENSTEIN \& BRAND, Olszewska p. 37, Pl. 6, Fig. 3.

Material: Lusina (140 P/39); Gródek nad Dunajcem (140 P/100, 140 P/120), Gródek nad Dunajcem (140 P/158).

Description: This species possesses a free, subglobular to somewhat flattened test with a proloculus followed by an irregularly enrolled early stage; later the chambers become more regular and possess a streptospirally coiled arrangement, and finally planispiral, about three to six chambers per whorl; the wall is calcareous, imperforate.

Distribution: Valanginian of Germany and England (Bartenstein and Brand, 1949); Valanginian to Barremian, Germany; Lowermost Aptian, Romania (Neagu, 1970b); Upper Berriasian of Ain, Savoie, France (Darsac, 1983); Berriasian-Valanginian of northwestern Anatolia, Turkey (Altiner, 1991); Berriasian of the West Balkan Mts., Bulgaria (Ivanova, 1999); Berriasian-Valanginian of the Cieszyn Beds, Polish Outer Carpathians (Olszewska, 2005).

Known range: Berriasian (Darsac, 1983; Altiner, 1991; Ivanova, 1999) - Lower Aptian (Neagu, 1970b).

Family Ophthalmidiidae WIESNER, 1920

Genus Ophthalmidium KUBLER \& ZWINGLI, 1870

Ophthalmidium sp. P1. 2, Fig. 20

Material: Lusina (140 P/85).

Description; The section found in the studied material is poorly preserved, oval in outline, flattened and possesses a globular proloculus followed by a narrow tubular flexostyle of up to one-half whorl in length; the wall is calcareous; the aperture at the end of a clearly visible neck.

Superfamily Miliolacea EHRENBERG, 1839

Family Hauerinidae SCHWAGER, 1876

Subfamily Hauerininae SCHWAGER, 1876

Genus Istriloculina NEAGU, 1984

Istriloculina eliptica (IOVCHEVA, 1962). Pl. 2, Figs. 22, 23

*1962 Pyrgo eliptica, IOVCHEVA p. 52, Pl. 2, Figs. 7-11.

1968 Pyrgo eliptica IOVCHEVA, Neagu p. 567, Pl. 1, Figs. 18-25.

1983 Pseudotriloculina sp., Darsac p. 217, Pl. 6, Figs. 5-7.

1986 Istriloculina elliptica (IOVCHEVA), Neagu p. 344, Pl. 5, Figs. 25-34; Figs. 6 a-m.

1993 Istriloculina eliptica (IOVCHEVA), Bucur et al., Pl. 6, Fig. 12.

1995 Istriloculina sp. cf. I. elliptica (IOVCHEVA), ArnaudVanneau and Sliter p. 556, Pl. 5, Figs. 13, 15, 17, 18.

2006 Istriloculina? sp., Kobayashi and Vuks, Pl. 5, 29-31.

Material: Gródek nad Dunajcem (140 P/84) and Woźniki $(140 \mathrm{P} / 31)$.

Description: Istriloculina eliptica possesses an elliptic up to high elliptic-elongate thin test with two chambers in the last

Studia UBB, Geologia, 2010, 55 (2), $3-31$ whorl, and without floors; the sutures are slightly depressed; the wall is very thin, calcareous, imperforate, porcelaneous.

Distribution: Aptian of the Ruse region, Bulgaria (Iovcheva, 1962); Barremian of the southern part of Dobrogea, Romania (Neagu, 1968, 1986); Middle-Upper Berriasian of Ain, Savoie, France (Darsac, 1983); Barremian of the Pădurea Craiului Mts., Romania (Bucur et al., 1993); Hauterivian-Lower Aptian of the western Mid-Pacific Mts. (Arnaud-Vanneau and Sliter, 1995).

Known range: Middle/Upper Berriasian (Darsac, 1983) Aptian (Iovcheva, 1962; Arnaud-Vanneau and Sliter, 1995). Istriloculina emiliae NEAGU, 1984. Pl. 2, Figs. 24-26

*1984 Istriloculina emiliae, NEAGU p. 88, Pl. 2, Figs. 22-25. 1985 Istriloculina emiliae NEAGU, Neagu p. 219, Pl. 5, Figs. 25-34; Fig. 6 a-m.

1989 Istriloculina fabaria, Matsieva \& Temirbekova p. 117, P1. 1, Figs. 1, m, n, o.

1989 Istriloculina rectoangularia, Matsieva \& Temirbekova p. 117, Pl. 1, Figs. p, r.

1989 Istriloculina terekensis, Matsieva \& Temirbekova

p. 118, Pl. 1, Figs. s, t, u.

2005 Istriloculina fabaria MATSIEVA \&

TEMIRBEKOVA, Olszewska p. 37, Pl. 6, Fig. 7.

2005 Istriloculina terekensis MATSIEVA \&

TEMIRBEKOVA, Olszewska p. 37, Pl. 6, Fig. 8.

2005b Istriloculina emiliae NEAGU, Gutowski et al., Fig. $10, \mathrm{~K}$.

2008 Istriloculina emiliae NEAGU, Ivanova et al., Fig. 7, K. Material: Lusina 140P/39; Gródek nad Dunajcem (140 $\mathrm{P} / 100,140 \mathrm{P} / 82,140 \mathrm{P} / 99)$, Gródek nad Dunajcem (140 $\mathrm{P} / 158)$.

Description: Istriloculina emiliae is characterised by its globular, ovate to subglobular test, with three chambers on each whorl, obviously Y-shaped; the chambers without floors; the sutures are depressed; the wall is thin, calcareous, imperforate and porcelaneous; aperture indistinct.

Distribution: Upper Berriasian-Valanginian southern part of Dobrogea, Romania (Neagu, 1984, 1985); Tithonian of the northeastern Caucasus (Matsieva and Temirbekova, 1989); Barremian of Pădurea Craiului Mts., Romania (Bucur, Cociuba and Cociuba, 1993); Tithonian-Berriasian of the Cieszyn Beds, Polish Outer Carpathians (Olszewska, 2005); Upper Berriasian-Valanginian of the Nizniow area, Western Ukraine (Gutowski et al., 2005b); BerriasianValanginian of southwestern Bulgaria (Ivanova et al., 2008). Known range: Tithonian (Matsieva and Temirbekova, 1989; Olszewska, 2005) -Barremian (Bucur et al., 1993).

Genus Moesiloculina NEAGU, 1984

Moesiloculina danubiana (NEAGU, 1968). Pl. 2, Figs. 27, 28

1968 Quinqueloculina danubiana Neagu p. 567, P1. 2 ,

Figs. 8-21.

1968 Quinqueloculina scythica, Neagu p. 567, Pl. 3, Figs. 112.

1968 Quinqueloculina histri Neagu p. 567, Pl. 3, Figs. 1323.

1986 Moesiloculina danubiana (NEAGU), Neagu p. 321, Pl.

4, Figs. 1-19; Pl. 9, Figs. 1-19; Text-Figs. 5 a-d.

1986 Moesiloculina scythica (NEAGU), Neagu p. 323, P1. 5, Figs. 1-19; Pl. 10, Figs. 39-43; Text-Fig. 4 f.

1986 Moesiloculina histri (NEAGU), Neagu p. 324, P1. 4, Figs. 20-36; Text-Fig. 3 g-h.

1986 Moesiloculina deformata Neagu p. 331, Pl. 6, Figs. 2030. 
1987 Quinqueloculina aff. danubiana NEAGU, ArnaudVanneau et al., Figs. A 25, 14, 19.

1993 Moesiloculina danubiana NEAGU, Bucur et al., P1. 6, Fig. 13.

2005b Moesiloculina danubiana NEAGU, Gutowski et al., Fig. 10, J.

Material: Woźniki (UJ 140P/31); Lusina (140P/39, 140P/41); Leńcze (140 P/83)

Description: Moesiloculina danubiana is characterized by its elongate, quinqueloculiniform test with triangular flattened chambers and concave lateral walls; very slightly depressed sutures.

Distribution: Barremian of Southern Dobrogea, Romania (Neagu, 1968); Upper Berriasian-Lower Aptian of the southern part of Dobrogea, Romania (Neagu, 1986); Berriasian-Lower Aptian of the Vocontian basin, Swiss Jura, France (Arnaud-Vaneau et al., 1987); Barremian of the Pădurea Craiului Mts., Romania (Bucur et al., 1993); Upper Berriasian-Aptian of the Nizniow area, Western Ukraine (Gutowski et al., 2005b).

Known range: Berriasian (Arnaud-Vaneau et al., 1987) Lower Aptian (Neagu, 1986)

Genus Quinqueloculina D’ORBIGNY, 1826

Quinqueloculina egmontensis LLOYD, 1962. Pl. 2, Figs. 29-36

*1962 Quinqueloculina egmontensis, Lloyd p. 376, P1. 2, Fig. 7a-c.

1964 Quinqueloculina podlubiensis Terestschuk (in Dulub \& Terestschuk) p. 107, Figs. 1, 1 a-g, 2.

1964 Quinqueloculina verbizhiensis Dulub (in Dulub \& Terestschuk) P. 108, Fig. 1, 3 a-g, 4.

1966 Quinqueloculina jurassica Bielecka and Styk p. 362, Pl. 1, Fig. 2 a-c.

1968 Quinqueloculina minima TAPPAN, Neagu p. 566, P1. 1, Figs. 1-7.

1968 Quinqueloculina robusta Neagu p. 566, P1. 1, Figs. 817; Pl. 7, Figs. 1-3.

1971 Quinqueloculina mitchurini Dain (in Dain and Kuznetsova) p. 114, P1. 1, Figs. 9, 10.

1983 Quinqueloculina robusta? NEAGU, Darsac p. 216, Pl. 6, Fig. 1.

1985 Rumanoloculina robusta (NEAGU), Neagu p. 213, P1. 5, Figs. 21-24.

1986 Rumanoloculina robusta (NEAGU), Neagu p. 315, Pl. 7, Figs. 23-25; P1. 8, Figs. 30-38; Text-Fig. 2.

1989 Quinqueloculina stellata Matsieva and Temirbekova, p. 115, Pl. 1, Figs. d, e, zh.

1989 Quinqueloculina verbizhiensis DULUB, Matsieva and Temirbekova p. 115, Pl. 1, Figs. z, i, k.

1991 Quinqueloculina robusta NEAGU, Altiner, Pl. 10, Figs. 1-4.

1993 Quinqueloculina podlubiensis TERESTSCHUK, Dulub \& Zhabina, Pl. 2, Fig. 3.

1993 Quinqueloculina aff. verbizhiensis DULUB, Dulub and Zhabina, P1. 2, Fig. 6.

1993 Quinqueloculina verbizhiensis DULUB, Dulub and Zhabina, P1. 2, Fig. 7.

1995 Rumanoloculina robusta (NEAGU), Bucur et al., Pl. 3, Figs. 6-9.

1999 Rumanoloculina robusta (NEAGU), Ivanova, P1. 2, Figs. 9, 10.

2002 Quinqueloculina sp., Voznesenskii et al., Pl. 2, Fig. 18. 2005 Decussoloculina barbui NEAGU, Olszewska p. 37, Pl. 6, Figs. 4, 5. 2005b Quinqueloculina verbizhiensis DULUB, Gutovski et al., P1. 10, C.

2005b Quinqueloculina podlubiensis TERESTSCHUK, Gutovski et al., P1. 10, D.

2007 Decussoloculina barbui NEAGU, Krajewski and Olszewska p. 303, Fig. 7, D.

2007 Quinqueloculina semisphaeroidalis DANITSCH, Krajewski and Olszewska p. 303, Fig.7, H.

2007 Rumanoloculina mitchurini DAIN, Krajewski and Olszewska p. 304, Fig. 7, E.

2007 Rumanoloculina verbizhiensis (DULUB), Krajewski and Olszewska p. 305, Fig. 7, I, J.

2008 Quinqueloculina robusta NEAGU, Ivanova et al., Fig. 7, C, D.

Material: Woźniki (140P/31); Jastrzębia (140 P/191); Lusina (140P/39, 140P/41); Gródek nad Dunajcem (140P/97, 140 P/99, 140 P/105, 140 P/118); Gródek nad Dunajcem (140 P/158).

Description: The species $Q$. egmontensis is characterised by its ovate, globular test with rounded periphery; the chambers with floors and quite thick added in quinqueloculine arrangement; the wall is calcareous, imperforate, and porcelaneous; the aperture is indistinct.

Distribution: Kimmeridgian of Dorset, England (Lloyd, 1962); Kimmeridgian-Tithonian of the southwestern margin of the Russian platform and Carpathian Foredeep (Dulub and Terestschuk, 1964); Uppermost Oxfordian Kimmeridgian of the Peri-Baltic Syneclise, Poland (1966); Barremian of the southern part of Dobrogea, Romania (Neagu, 1968); Tithonian of the Russian platform (Dain and Kuznetsova, 1971); Middle-Upper Berriasian of Ain, Savoie, France (Darsac, 1983); Upper Berriasian-Lower Aptian of the southern part of Dobrogea, Romania (Neagu, 1984, 1985, 1986); Middle Berriasian-Lower Valanginian of the Vocontian basin, Swiss Jura, France (Arnaud-Vanneau et al., 1987); Tithonian of northeastern Caucasus (Matsieva and Temirbekova, 1989); Upper Tithonian to Valanginian of northwestern Anatolia, Turkey (Altiner, 1991); Berriasian of southeastern Crimea (Dulub and Zhabina, 1993); Berriasian-Valanginian of the Jerma River canyon, Eastern Serbia (Bucur et al., 1995); Berriasian of the West Balkan Mts., Bulgaria (Ivanova, 1999); BarremianAptian of southeastern part of the Lesser Caucasus (Voznesenskii et al., 2002); Middle TithonianValanginian of the Cieszyn Beds, Polish Outer Carpathians (Olszewska, 2005); KimmeridgianBerriasian of the Nizniow area, Western Ukraine (Gutowski et al., 2005b); Kimmeridgian-Lower Valanginian of the southern part of the Crimea Mts., Southern Ukraine (Krajewski and Olszewska, 2007); Upper Tithonian-Valanginian of southwestern Bulgaria (Ivanova et al., 2008).

Discussion: The genus Quinqueloculina includes many species which are morphologically highly variable. During the study of carbonate sediments we ascertain that many of the species introduced as new for the Upper Jurassic-Lower Cretaceous interval (Dulub and Terestschuk, 1964; Bielecka and Styk, 1966; Dain and Kuznetsova, 1971; Neagu, 1968, 1984, 1985, 1986; Matsieva and Temirbekova, 1989) are synonyms and requires revision.

Known range: Uppermost Oxfordian (Bielecka and Styk, 1966) - Albian (Neagu, 1984, 1985, 1986). 
Quinqueloculina multicostata NEAGU, 1968. P1. 2, Figs. 33,37

*1968 Quinqueloculina multicostata, Neagu p. 566, P1. 4, Figs. 1-7.

1985 Rumanoluculina multicostata primitiva n. ssp., Neagu p. 214, P1. 5, Figs. 9-14.

Material: Woźniki, UJ 140P/31.

Description: This species is characterized by its quinqueloculinid chamber arrangement, whit depressed sutures between them and fine, numerous ribs which give specific ornamentation of the test surface.

Distribution: Barremian of the southern part of Dobrogea, Romania (Neagu, 1968); Upper Berriasian-Lower Aptian of the southern part of Dobrogea, Romania (Neagu, 1984, 1985, 1986); undivided Berriasian-Valanginian of Fara San Martino, Maiella, Italy (Bruni et al., 2007).

Known range: Upper Berriasian-Lower Aptian (Neagu, 1984, 1985, 1986).

Order Lagenida LANKESTER, 1885

Superfamily Nodosariacea EHRENBERG, 1838

Family Vaginulinidae REUSS, 1860

Subfamily Lenticulininae CHAPMAN, PARR \&COLLINS, 1934

Genus Lenticulina LAMARCK, 1804

Lenticulina sp. P1. 2, Fig. 6

Material: Lusina (140P/39); Gródek nad Dunajcem (140P/32).

Description: The observed section possesses an enrolled and compressed test, the early portion is coiled, and later uncoiled; chambers are low and elongate; the wall is calcareous. This section is refered to $L$. ex. gr. muensteri (Roemer, 1839) which is interpreted as relict Jurassic group (see Jones and Wonders, 1992, P1. 2, Figs. 10, 11).

Order Rotaliida LANKESTER, 1885

Superfamily Discorbacea EHRENBERG, 1838

Family Discorbidae EHRENBERG, 1838

Genus Mohlerina BUCUR, SENOWBARI-DARYAN \& ABATE, 1996

Mohlerina basiliensis (MOHLER, 1938). Pl. 5, Figs. 1218

*1938 Conicospirillina basiliensis, Mohler p. 27, Pl. 4, Fig. 5.

1956 Conicospirillina $\mathrm{cf}$. basiliensis MOHLER,

Weynschenk, P1. 1, Figs. 9-10.

1983 Conicospirillina basiliensis MOHLER, Darsac p. 217, P1. 6, Figs. 21-22.

1993 Archaeosepta basiliensis nov. comb., Tasli p. 60, P1. 3, Fig. 6, 7 (Synonymy).

1996 Mohlerina basiliensis MOHLER nov. comb., Bucur et al. p. 70, P1. 3, Figs. 3-6; P1. 4, Figs. 2, 3, 5-9 (Synonymy).

2001 Mohlerina basiliensis MOHLER, Olszewska and Wieczorek, P1. 4, Fig. 6.

2004 Mohlerina basiliensis MOHLER, Bucur et al., Pl. 1, Fig. 2.

2005 Mohlerina basiliensis MOHLER, Olszewska p. 38, Pl. 6, Fig. 1.

2005 Mohlerina basiliensis MOHLER, Bucur and Săsăran, P1. 2, Fig. 12.

2005 Mohlerina basiliensis MOHLER, Schlagintweit et al. p. 33, P1. 16: a-c (Synonymy).

2007 Mohlerina basiliensis MOHLER, Krajewski and Olszewska p. 305, Fig. 8, A.

2008 Mohlerina basiliensis MOHLER, Ivanova et al., Fig. 6, N, Q.
Material: Gródek nad Dunajcem (140 P/81, 140 P/84, 140 $\mathrm{P} / 99,140 \mathrm{P} / 115)$; UJ 140P/36 Zamarski, $140 \mathrm{P} / 115$; to chyba Lusina 140 P/39, Gródek nad Dunajcem (140 P/158).

Remarks: The detailed description of the species and arguments for the creation of the new combination Mohlerina are given by: Tasli, 1993; Bucur et al., 1996; Schlagintweit et al., 2005.

Distribution: Upper Jurassic of Switzerland (Mohler, 1938); Middle/Upper Dogger and lowermost Malm of Sonnwend Mountain, Tyrol, Austria (Weynschenk, 1956); Middle/Upper Berriasian of Ain, Savoie, France (Darsac, 1983); Upper Kimmeridgian or Tithonian of the KaleGümüşhane region, Eastern Pontids, Turkey (Tasli, 1993); Upper Tithonian of the Madonie Mts., Italy (Bucur et al., 1996); Oxfordian-Valanginian of the Cieszyn Beds, Polish Outer Carpathians (Olszewska, 2005); Upper OxfordianValanginian of the Apuseni Mountains, Romania (Bucur and Săsăran, 2005); Upper Kimmeridgian-Lower Berriasian Plassen carbonate platform, Northern Calcareous Alps (Schlagintweit et al., 2005); Middle Oxfordian - Lower Valanginian of the southern part of the Crimea Mts., Southern Ukraine (Krajewski and Olszewska, 2007); Upper Kimmeridgian - Lower Berriasian of southwestern Bulgaria (Ivanova et al., 2008).

Known range: Middle Dogger (Weynschenk, 1956) Valanginian (Schlagintweit and Ebli, 1999; Olszewska, 2005; Bucur and Săsăran, 2005).

\section{CONCLUSION}

Our study of exotic pebbles to small boulders of the Stramberk-type limestones from the Polish Outer Carpathians revealed 34 species of foraminifera (including 8 in open nomenclature) representing 30 genera, 22 families, 14 superfamilies, 11 suborders, and 7 orders. The studied limestones can be attributed to reef and peri-reef facies, and lagoonal algal-foraminiferal facies (the latter facies contain more stratigraphically important species). Age determination was possible only for 30 exotics. Fifteen of them are not older than Tithonian, 13 - not older than Berriasian, and at least 2 of them are Valanginian. The age based on foraminifera is only partly in agreement with the previous studies of calpionellids and ammonites which indicated a Tithonian-Early Berriasian age. However, Valanginian shallow-water limestones have already been known as pebbles in some deposits of the Outer Carpathians in the Czech Republic. Further evidence for Valanginian shallow-water marine carbonate sedimentation (algal facies) comes from recent studies of the substrate drilled in the Carpathian Foredeep. Thus, shallow-water marine sedimentation, mainly as lagoonal facies, persisted on the northern segment of the Tethyan margin into the Valanginian.

Acknowledgements. This work was undertaken in the framework of the project Integrated paleontological, stratigraphical, and sedimentological study of the Upper Jurassic-Lower Cretaceous carbonate platforms from Western Bulgaria and Southern Poland funded by the Bulgarian Academy of Sciences and the Polish Academy of Sciences, and it is a contribution to the project NZ-1516/05. D.I. was supported by the Queen Jadwiga Fund (Jagiellonian University, Kraków). We are thankful to the two reviewers for their constructive comments and critical remarks that imporved both the text and its English. 


\section{R E F E R E N C E S}

Altiner, D. 1991, Microfossil biostratigraphy (mainly Foraminifers) of the Jurassic-Lower Cretaceous carbonate successions in North-Western Anatolia (Turkey). Geologica Romana, 27: 167-215.

Arkad'ev, V., Fedorova, A., Savel'eva, Y. u. \& Tesakova, E. 2006, Biostratigraphy of the Jurassic-Cretaceous boundary beds in the Eastern Crimea. Stratigraphy and Geological Correlation, 14 (3): 84-113 (in Russian).

Arnaud-Vanneau, A., Arnaud, H., Adatte, Th., Argot, M., Rumley, G. \& Thieuloy, J.-P. 1987, The Lower Cretaceous from the Jura Platform to the Vocontian Basin (Swiss Jura, France). Field trip guide book, Excursion D, III International Cretaceous Symposium, Tuebingen, p. 1-128.

Arnaud-Vanneau A., Boisseau, T. \& Darsac, C. 1988, Le genre Trocholina Paalzow 1922 et ses principales especes au Crétacé. Revue de Paléobiologie, Spec. vol. 2, Benthos'86, 353-377.

Arnaud-Vanneau, A., Masse, J.-P. 1989, Les Foraminifères benthiques des formations carbonatées de l'HauterivienBarremien pro parte du Jura Vaudois et Nuechatelois (Suisse). Mémoires de la Societé neuchâteloise des Sciences naturelles, 11: 257-276.

Arnaud-Vanneau, A., Peybernès, B. 1978, Les representants éocrétacés du genre Nautiloculina Mohler, 1938 (Foraminifera, fam. Lituolidae?) dans les chaines subalpines septentrionales (Vercors) et les Pyrenées Franco-Espagnoles. Révision de Nautiloculina cretacea Peybernès, 1976 et description de Nautiloculina bronnimanni n. sp. Geobios, 11 (1): 67-81.

Arnaud-Vanneau, A., Sliter, W. 1995, Early Cretaceous shallow-water benthic foraminifers and fecal pellets from Leg 143 compared with coeval faunas from the Pacific basin, Central America, and the Tethys. Proceedings of the Ocean Drilling Program, Scientific Results, 143: 537-564.

Barski M., Matyja B.A. 2008, Stratigraphy of Late Jurassic basement of the Carpathian Foreland based on microfossils. - In Utwory przełomu jury $i$ kredy $w$ zachodnich Karpatach fliszowych polsko-czeskiego pogranicza, Jurassica VII, (Krobicki M., Ed.), Żywiec/Štramberk. Kwartalnik AGH Geologia, 3 (1): 163-164 (in Polish).

Bartenstein, H., Brand, E. 1949, New genera of Foraminifera from the Lower Cretaceous of Germany and England. Journal of Paleontology, 23 (6): 669-672.

Bielecka, W., Styk, O. 1966, The Malmian Microfauna in the Southern Part of the Peri-Baltic Syneclise. Kwartalnik Geologiczny, 10 (2): 350-367 (in Polish with English summary).

Bobrek, L., Świetlik, B. \& Urbaniec, A. 2005, Microfossils assemblages from the Valanginian deposits in Czarna Tarnowska-Dębica region. V Jubileuszowe Warsztaty Mikropaleontologiczne, Szymbark, p. 36-37 (in Polish).

Brönnimann, P., Conrad, M.A. 1967, Cinquième note sur les foraminifèrs du Crétacé inférieur de la région genevoise. Melathrokerion valserinensis n. gen., n. sp., un foraminifère nouveau du Barrémien à faciès urgonien dans le Jura français. Compte Rendu des Seances de la Societe de Physique et d'Histoire Naturelle de Geneve, 1: 129-151.
Bruni, R., Bucur, I.I. \& Preat, A. 2007, Uppermost JurassicLower Cretaceous carbonate deposits from Fara San Martino (Maiella, Italy): biostratigraphic remarks. Studia Universitatis Babeş-Bolyai, Geologia, 52 (2): 45-54.

Bucur, I.I. 1988, Les foraminifères du Crétacé inférieur (Berriasian-Hauterivian) de la zone de Reşiţa-Moldova Nouă (Carpathes Méridionales, Roumanie). Remarques biostratigraphiques. Revue de Paléobiologie, Spec. vol. 2, Benthos'86: 379-389.

Bucur, I.I. 1993, Representatives of the genus Protopeneroplis Weynschenk from the Lower Cretaceous deposits in the Reşița-Moldova Nouă Zone (Southern Carpathians, Romania). Revue de Micropaléontologie, 36 (3): 213-223.

Bucur, I.I. 1997, Representatives of the genus Protopeneroplis (Foraminifera) in the Jurassic and Lower Cretaceous deposits in Romania. Comparisons with other regions of the Tethyan area. Acta Palaeontologica Romaniae, 1: 65-71.

Bucur, I.I., Cociuba, J. \& Cociuba, M. 1993, Microfacies and microfossils in the Upper Jurassic-Lower Cretaceous Limestone in the Southern part of the Pădurea Craiului Mountains. Romanian Journal of Stratigraphy, 75: 33-40.

Bucur, I.I., Conrad, M. \& Radoičić, R. 1995, Foraminifers and calcareous algae from Valanginian Limestones in the Jerma river canyon, Eastern Serbia. Revue de Paléobiologie, 14 (2): 349-377.

Bucur, I.I., Hoffmann, M. \& Kolodziej, B. 2005, Upper Jurassic-Lowermost Cretaceous benthic algae from Tethys and the European platform: A case study from Poland. Revista Espanola Micropaleontología, 37 (1): 105-129.

Bucur, I.I., Koch, R., Kirmaci, Z. \& Tasli, K. 2004, Foraminifères du Jurassique supérieur et du Cretacé inférieur (Calcaire de Berdiga) de Kircaova (région de Kale-Gümüshane, NE Turquie). Revue de Paléobiologie, 23 (1): 209-225.

Bucur, I.I., Sasărăn, E. 2005, Micropaleontological assemblages from the Upper Jurassic-Lower Cretaceous deposits of Trascău Mountains and their biostratigraphic significance. Acta Palaeontologica Romaniae, 5: 27-38.

Bucur, I.I., Senowbari-Daryan, B. \& Abate, B. 1996, Remarks on some foraminifera from the Upper Jurasic (Tithonian) reef limestone of Madonie Mountains (Sicily). Bollettino della Società Paleontologica Italiana, 35 (1): 65-80.

Canérot, J. 1984, Fluctuations marines et evolution biologique: exemple du Neocomien des Iberides orientales (Espagne). Bentos'83, $2^{\text {nd }}$ Int. Symp. Benthic Foraminifera, Pau, April 1983, p. 131-139.

Charollais, J., Broennimann, P. \& Zaninetti, L. 1966, Troisième note sur les foraminifères du Crétacé inférieur de la région genevoise. Remarques stratigraphiques et description de Pseudotextulariella salevensis, n. sp.; Haplophragmoides joukowskyi, n. sp.; Citaella? favrei, n. sp. Archives des Sciences, Genève, 19 (1): 23-48.

Cherchi, A., Schroeder, R. 2006, Remarks on the systematic position of Lithocodium Elliott, a problematic microorganism from the Mesozoic carbonate platforms of the Tethyan realm. Facies, 52: 435-440.

Ciborowski, T., Kołodziej, B. 2001, Tithonian-Berriasian calpionellids from the Stramberk-type limestones, Polish 
Flysch Carpathians. Geologica Carpathica, 52 (6): 343348.

Cushman, J., Alexander, C. 1930, Some Vaginulinas and other foraminifera from the Lower Cretaceous of Texas. Contributions from the Cushman Laboratory for Foraminiferal Research, 6: 1-10.

Dain, L., Kuznetsova, K. 1971, Zonal subdivision of the stratotypical section of the Volgian stage based on Foraminifera. Voprosy Micropaleontologii, 14: 114-124 (in Russian).

Darsac, C. 1983, La plate-forme berriasien-valanginienne du Jura méridional aux massifs subalpins (Ain, Savoie). Unpubl. PhD Thesis, Univ. Sci. Medicale Grenoble, p. 1-319.

Decrouez, D., Morycowa, E. 1997, Microfossils from the Tithonian exotic limestone in Woźniki (External Carpathians, Poland). Annales Societatis Geologorum Poloniae, 67: 197-201.

Dieni, I., Massari, F. 1966, I foraminiferi del Valanginiano superiore de Orosei (Sardegna). Palaeontographica Italica, 61: 75-186.

Dragastan, O., Richter, D. 2003, Calcareous algae and foraminifers from Neocomian limestones of Methana Peninsula, Asprovouni Mts. (Greece) and from south Dobrogea (Romania). Analele Universitatii Bucuresti, Geology, Spec. Publ., 1: 57-128.

Dulub, V., Terestschuk, A. 1964, Representatives of Miliolids from the Jurassic sediments the Southwest margine of the Russian platform and Forecarpathian Foredeep. Trudy Ukrainkii Nauchno-Issledovatelskoi Geologo-Razvedochnoi Institut (NIGRI), 9: 106-111 (in Russian).

Dulub, V., Zhabina, N. 1993, Distribution and Habitat Conditions of the Tithonian and Berriasian Foraminifers in the South-Eastern Crimea. Geologicheskii Zhurnal, 1: 102-113 (in Russian).

Eliáš, M., Eliášová, H. 1984, Facies and palaeogeography of the Jurassic in the western part of the Outer Flysch Carpathians in Czechoslovakia. Sbornik gelogických vĕd, 39: 105-170.

Eliáš, M., Eliášová, H. 1986, Elevation facies of the Malm in Moravia. Geologický Zbornik - Geologica Carpathica, 37 (4): 532-550.

Eliáš, M., Vašíček, V. 1995, Early Berriasian ammonites from the Štramberk Limestone of Kotouč quarry (Outer Carpathians, Silesian Unit, Štramberk, Czech Republic). Véstník Českého geologického ústavu, 70: 1-32.

Geroch, S., Morycowa, E. 1966, Contribution á la connaissance des faciès et fossiles des calcaires tithoniques à Kruhel Wielki près Przemyś 1 (Carpathes de Flysch, Pologne). Rocznik Polskiego Towrzystwa Geologicznego, 36: 295301 (in Polish with French summary).

Golonka, J., Oszczypko, N. \& Ślączka, A. 2000, Late Carboniferous-Neogene geodynamic evolution and paleogeography of the Circum-Carpathian region and adjacent areas. Annales Societatis Geologorum Poloniae, 70: 107-136.

Gorbachik, T. 1968, Homeomorphy of foraminifera. Paleontologicheskii Zhurnal, 1: 3-10 (in Russian).

Gorbachik, T. 1971, On Early Cretaceous foraminifera of the Crimea. Voprosy Micropaleontologii, 14: 125-139 (in Russian).

Gutowski, J., Popadyuk, I. \& Olszewska, B. 2005a, Late Jurassic-earliest Cretaceous evolution of the

Studia UBB, Geologia, 2010, 55 (2), 3 - 31 epicontinental sedimentary basin of southeastern Poland and Western Ukraine. Geological Quarterly, 49 (1): 3144.

Gutowski, J., Popadyuk, I. \& Olszewska, B. 2005b, Stratigraphy and facies development of the upper Tithonian-lower Berriasian Nizniow Formation along the Dnister River (Western Ukraine). Geological Quarterly, 49 (1): 45-52.

Gutowski, J., Urbaniec, A., Złonkiewicz, Z., Bobrek, L., Świetlik, B. \& Gliniak, P. 2007, Upper Jurassic aand Lower Cretaceous of the middle Polish Carpathian Foreland. Biuletyn Państwowego Instytutu Geologicznego, 426: 1-26 (in Polish with English summary).

Haeusler, R. 1890, Monographie der Foraminiferen-Fauna der schweizerischen Transversarius-Zone. Abhandlungen der Schweizerischen paläontologischen Gesellschaft, 17, $134 \mathrm{p}$.

Heinz, R., Isenschmid, Ch. 1988, Mikrofazielle und stratigraphische Untersuchungen im Massivenkalk (Malm) der Prealpes medians. Eclogae Geologicae Helvetiae, 81 (1): 1-62.

Hoffmann, M., Kołodziej, B. 2004, Sedimentary environment of Štramberk-type limestones from Western Flysch Carpathians. VIII. Krajowe Spotkanie Sedymentologów, Zakopane, 21-24. 05. 2004, Materiały konferencyjne: 91 (in Polish).

Hoffmann, M., Kołodziej, B. 2008, Facies differentiation of Štramberk-type limestones. - In Utwory przełomu jury $i$ kredy $w$ zachodnich Karpatach fliszowych polskoczeskiego pogranicza, Jurassica VII, (Krobicki, M., Ed.), Żywiec/Štramberk, 27-29.09.2008. Kwartalnik AGH Geologia, 3 (1): 176-177 (in Polish).

Hoffmann, M., Kołodziej, B., Bucur, I.I. \& Săsăran, E. 2008, Role of microbialites, microencrusters and synsedimentary cement in reef constructions from Stramberk -type limestones from Poland and Romania. In Utwory przełomu jury $i$ kredy $w$ zachodnich Karpatach fliszowych polsko-czeskiego pogranicza, Jurassica VII, (Krobicki, M., Ed.), Żywiec/Štramberk, Żywiec/Štramberk, 27-29.09.2008. Kwartalnik AGH Geologia, 3 (1): 178-179 (in Polish).

Hottinger, L. 1967, Foraminifères imperforés du Mesozoique marocain. Notes et Memoires du Service Geologique, 209: 1-168.

Houša, V. 1983, The origin of the bodies of the Štramberk Limestone near Štramberk. Sbornik gelogických věd, 58: 193-203 (in Czech).

Houša, V. 1990, Stratigraphy and calpionellid zonation of the $\breve{S}$ tramberk Limestone and associated Lower Cretaceous beds. Atti del secondo convegno internazionale Fossili, Evoluzione, Ambient, Pergola, October 25-30, 1987, p. 365-370.

Hughes, G.W. 2004. Palaeoenvironmental and sequence stratigraphic implication of Pseudocyclammina lituus events in the Upper Jurassic (Oxfordian) Hanifa Formation of Saudi Arabia. In Proceedings of the $6^{\text {th }}$ International Workshop on Agglutinated Foraminifera (Bubik, M., Kaminski, M.A., Eds.), Grzybowski Foundation Special Publication, 8: 209-216.

Husinec, A., Sokač, B. 2006, Early Cretaceous benthic associations (foraminifera and calcareous algae) of shallow tropical-water platform environment (Mljet Island, southern Croatia). Cretaceous Research, 27: 418-441. 
Iovcheva, P. 1962, Foraminifera from the oolitic limestones of the Aptian along the Rusenski Lom River. Review of the Bulgarian Geological Society, 23: 41-61.

Ivanova, D. 1999, Middle Callovian to Valanginian microfossil biostratigraphy in the West Balkan Mountain, Bulgaria (SE Europe). Acta Palaeontologica Romaniae, 2: 231-236.

Ivanova, D., Koleva-Rekalova, E. 2004, Agglutinated foraminifers in the framework of Southwestern Bulgarian palaeoenvironmental evolution during the Late Jurassic and Early Cretaceous. In Proceedings of the $6^{\text {th }}$ International Workshop on Agglutinated Foraminifera (Bubik, M., Kaminski, M.A., Eds.), Grzybowski Foundation Special Publication, 8: 217-227.

Ivanova, D., Kołodziej, B. 2004, New foraminiferal data on the age of Stramberk-type limestones, Polish Carpathians. Comptes Rendus de l'Académie bulgare des Sciences, 57 (12): 69-74.

Ivanova, D., Kołodziej, B., Koleva-Rekalova, E. \& Roniewicz, E. 2008, Oxfordian to Valanginian palaeoenvironmental evolution on the western Moesian Carbonate Platform: a case study from SW Bulgaria. Annales Societatis Geologorum Poloniae, 78: 65-90.

Jones, R.W., Wonders, A.A.H. 1992, Benthic foraminifers and paleobathymetry of Barrow Group (BerriasianValanginian) deltaic sequences, sites 762 and 763 , Northwest shelf, Australia. Proceedings of the Ocean Drilling Program, Scientific Results, 122: 557-568.

Kaminski, M.A. 2004, The Year 2000 Classification of the Agglutinated Foraminifera. - In Proceedings of the $6^{\text {th }}$ International Workshop on Agglutinated Foraminifera, (Bubik, M., Kaminski, M.A., Eds.), Grzybowski Fondation Special Publication, 8: 237-255.

Kaminski, M.A., Gradstein, F. \& Geroch, S. 1992, Uppermost Jurassic to Lower Cretaceous deep-water benthic foraminiferal assemblages from Site 765 on the Argo Abyssal Plain. Proceedings of the Ocean Drilling Program, Scientific Results, 123: 239-269.

Kobayashi, F., Vuks, V. 2006, Tithonian - Berriasian foraminiferal faunas from the Torinosu-type calcareous blocks of the southern Kanto Mountains, Japan: their implications for post-accretionary tectonics of Jurassic to Cretaceous terranes. Geobios, 39 (6): 833-843.

Kołodziej, B. 1997, Boring Foraminifera from exotics of Štramberk-type limestones (Tithonian-lower Berriasian, Polish Carpathians). Annales Societatis Geologorum Poloniae, 67: 249-256.

Kołodziej, B. 2003, Scleractinian corals of suborders Pachythecaliina and Rhipidogyrina (Scleractinia): discussion on similarities and description of species from Štramberk-type limestones, Polish Outer Carpathians. Annales Societatis Geologorum Poloniae, 73: 193-217.

Kołodziej, B., Decrouez, D. 1997, Foraminifera and incertae sedis from the Stramberk-type limestone (TithonianBerriasian). Preliminary results. Revue de Paléobiologie, 16 (1): 145-150.

Krajewski, M., Olszewska, B. 2007, Foraminifera from the Late Jurassic and Early Cretaceous carbonate platform facies of the southern part of the Crimea Mountains, Southern Ukraine. Annales Societatis Geologorum Poloniae, 77: 291-311.

Król, K., Decrouez, D. 2002, Age and depositional environment of exotic limestones from Zamarski in
Lower Cieszyn shales. Revue de Paléobiologie, 21 (1): 193-198.

Książkiewicz, M. 1935, Die äusere karpatische Klippenzone bei Andrychów. III. Die stratigraphie der Klippenserie und ihre Stellung im Bau der West-Karpaten. Bulletin de l'Académie Polonaise des Sciences et des Lettres, Série A, p. 221-233.

Książkiewicz, M. 1965, Les cordilléras dans les mers crétacées et paléogènes des Carpathes du Nord. Bulletin de la Société géologique de France, Série 7 (7): 443445.

Książkiewicz, M. 1971, On origin of the Inwałd Limestones (Outer Carpathian Klippes). Bulletin de l'Academie polonaise des Sciences, Série des Sciences de la Terre, 19 (2): 91-98.

Kuznetsova, K. 1974, Distribution of benthonic foraminifera in Upper Jurassic and Lower Cretaceous deposits at Site 261, DSDP LEG 27, in the Eastern Indian Ocean. Initial Report of Deep Sea Drilling Project, 27: 673-681.

Laug, B., Peybernès, B. \& Rey, J. 1980, Mayncina bulgarica n. sp. Lituolide nouveau du Crétacé inférieur mésogeen (Bulgarie, Portugal, Pyrenées, Tunisie). Bulletin de la Société d'Histoire Naturelle de Toulouse, 116 (1-2): 68-76.

Lloyd, A. 1962. Polymorphinid, miliolid and rotaliform foraminifera from the type Kimmeridgian. Micropaleontology, 8 (3): 369-383.

Loeblich, A., Tappan, H. 1985, Some new and redefined genera and families of agglutinated foraminifera. I. Journal Foraminiferal Research, 15 (2): 91-104.

Loeblich, A., Tappan, H. 1987, Foraminiferal genera and their classification. 1. Text and Indices, New York (Van Nostrand), $970 \mathrm{p}$.

Loeblich, A., Tappan, H. 1992, Present status of foraminiferal classification. Studies in Benthic Foraminifera, Benthos'90: 93-102.

Maksym, A., Baszkiewicz, A., Gregosiewicz, Z., Liszka, B. \& Zdanowski, P. 2001, Facies and reservoir potential of upper most Jurassic and Lower Cretaceous deposits in the Brzezówka- Zagorzyce region versus geologic structure of the southern Carpathians. Przeglad Geologiczny, 49 (5): 401-407 (in Polish with English summary).

Malata, E., Malata, T. \& Oszczypko, N. 1996, Litho- and biostratigraphy of the Magura Nappe in the eastern part of the Beskid Wyspowy Range (Polish Western Carpathians). Annales Societatis Geologorum Poloniae, 66: 269-284.

Malik, K. 1986, Turbidite facies and fan-facies associations in the Cieszyn Limestones (Upper Tithonian-Berriasian, northwestern Carpathians, Poland). IAS $7^{\text {th }}$ European Regional Meeting. Excursion Guidebook, Ossolineum Publishing House of the Polish Academy of Sciences, Wrocław, p. 53-66.

Mancinelli, A., Coccia, B. 1999, Le Trocholine dei sedimenti mesozoici di piattaforma carbonatica dell'Appennino centro-meridionale (Abruzzo e Lazio). Revue de Paléobiologie, 18 (1): 147-171.

Matsieva, T., Temirbekova, U. 1989, Tithonian miliolids of the North-Eastern Caucasus (Terek river basin). Paleontologicheskii Zhurnal, 4: 114-118. (in Russian)

Matyja, B.A. 2009, Development of the Mid-Polish Trough versus Late Jurassic evolution in the Carpathian Foredeep. Geological Quarterly, 53 (1): 49-62. 
Matyszkiewicz, J., Słomka, T. 2004, Reef-microencrusters association Lithocodium aggregatum-Bacinella irregularis from the Cieszyn Limestone (TithonianBerriasian). Geologica Carpathica, 55 (6): 449-456.

Mjatliuk, E. 1939, Foraminifera of the Upper Jurassic and Lower Cretaceous of the region of the Middle Volga River and the Great Syrte. Trudy VNIGRI, 120: 1-76 (in Russian).

Mohler, W. 1938, Mikropaleontologische Untersuchungen in der nordschweizerischen Juraformation. Abhandlungen der Schweizerischen paläontologischen Gesellschaft, 60: 1-53.

Moryc, W. 1997, The Lower Cretaceous in the Pre-Miocene Substratum of the southern part of the Carpathian Foredeep in Poland. Annales Societatis Geologorum Poloniae, 67: 287-296.

Morycowa, E. 1964, Polypiers de la klippe de Kruhel Wielki près de Przemyśl (Tithonique, supérieur, Carpathes polonaises). Rocznik Polskiego Towarzystwa Geologicznego, 34 (4): 489-508.

Morycowa, E. 1968, Sur les calcaires exotique a Madréporaires dans les Lac Rożnów (Carpathes polonaises de Flysch). Rocznik Polskiego Towarzystwa Geologicznego, 38: 19-32.

Morycowa, E. 1974, Hexacorallia d'un bloc exotique de calcaire á Woźniki près Wadowice (Carpathes polonaises occidentales). Acta Geologica Polonica, 24 (3): 457-484.

Morycowa, E., 1985, Upper Jurassic Hexacorallia in the foreland of the Polish Carpathians. Proceeding Reports, $13^{\text {th }}$ Congress, Carpatho-Balkan Geological Association, Poland - Cracow. September 5-10, 1985, Part I: 52-56.

Morycowa, E. 1988, Klippes of Kruhel Wielki. In Przewodnik LIX Zjazdu Pol. Tow. Geol. (Kotlarczyk, J., Ed.), Przemyśl 16-18.09.1988, Kraków, p. 259-266 (in Polish)

Morycowa, E., Moryc, W. 1976, The Upper Jurassic sediments in the Foreland of the Polish Carpathians (Sandomierz Basin). Rocznik Polskiego Towarzystwa Geologicznego, 46: 231-288 (in Polish with English summary).

Neagu, T. 1968, Study of the Miliolidaceae in the Lower Cretaceous (Barremian) of Southern Dobrogea. Travaux du Museum d'Histoire Naturelle „Grigore Antipa“, 8: 563-572.

Neagu, T. 1970a, The genus Meandrospira (Foram.) from Lower Cretaceous strata in Romania. Senckenbergiana Lethea, 51 (5-6): 411-415.

Neagu, T. 1970b, The genus Hechtina (Foram., Lower Cretaceous) and its systematical position. Senckenbergiana Lethea, 51 (5-6): 417-425.

Neagu, T. 1979, Données nouvelles concernant les représentants de la famille des Pfenderinidae de l'Eocretace de la Dobrogea méridionale (Roumanie). Revista Española Micropaleontología, 11 (3): 479-504.

Neagu, T. 1984, Nouvelles données sur la morphologie du test, sur la systematique et la nomenclature des Miliolidés agatistheques du Mésozoique. Revista Española Micropaleontología, 16 (1-3): 75-90.

Neagu, T. 1985, Berriasian-Valanginian miliolid fauna of the Southern Dobrogea (Romania). Revista Española Micropaleontología, 17 (2): 201-220.
Neagu, T. 1986, Barremian-Lower Aptian miliolid fauna in Southern Dobrogea (Romania). Revista Española Micropaleontología, 18 (3): 313-348.

Neagu, T. 1997, Lower Cretaceous agglutinated foraminifera from the Superfamilies Verneuilinacea and Ataxophragmiacea; Southern Dobrogea, Romania. Annales Societatis Geologorum Poloniae, 67: 307-323.

Neagu, T. 1999, Lower Cretaceous calcareous agglutinated foraminifera from Southern Dobrogea - Romania. Part IV. Miscelianea (Litulolacea, Biokovinacea and Loftusiacea - some new taxa). Acta Palaeontologica Romaniae, 2: 287-304.

Neagu, T., Neagu, M. 1995, Smaller agglutinated foraminifera from the acanthicum Limestone (Upper Jurassic), Eastern Carpathians, Romania. - In Proceedings of the $4^{\text {th }}$ International Workshop on Agglutinated Foraminifera (Kaminski, M.A., Geroch, S. \& Gasinski, M., Eds), Grzybowski Foundation Special Publication, 3: 211-225.

Neumann, M. 1965, Contribution a l'étude de quelques Lituolidés du Cénomanien de l'ile Madame (Charente Maritime). Revue de Micropaléontologie, 8 (2): 90-95.

Niemczycka, T. 1976a, Upper Jurassic rocks of the eastern Poland area (between the Vistula and the Bug rivers). Prace Instytutu Geologicznego, 77: 5-99 (in Polish with English summary).

Niemczycka, T. 1976b, Lithostratigraphy of Upper Jurassic deposits in the Lublin-Radoam area. Acta Geologica Polonica, 26: 569-601 (in Polish with English summary).

Nowak, W. 1976, The Outer (Flysch) Carpathians. In Geology of Poland, v. 1, part 2, Stratigraphy. Mesozoic, Wydawnictwa Geologiczne (Sokołowski, S., Ed.), Warszawa, p. 401-421 (in Polish).

Olszewska, B. 1999, Thin section microbiostratigraphy of the well Zagorzyce 6. Biuletyn Państwowego Instytutu Geologicznego, 387: 149-153.

Olszewska, B. 2001, Malm and Neocomian stratigraphy of the flysh Carpathian basement derived from recent micropaleontologic data. Przeglad Geologiczny, 49 (5): 451 (in Polish).

Olszewska, B. 2005, Microfossils of the Cieszyn Beds (Silesian Unit, Polish Outer Carpathians) - a thin sections study. Polish Geological Institute, Special Papers, 19: 1-58.

Olszewska, B., Wieczorek, J. 2001, Jurassic sediments and microfossils of the Andrychow Klippes (Outer Western Carpathians). Geologica Carpathica, 52 (4): 217-228.

Omaña, L., González Arreola, C. 2008, Late Jurassic (Kimmeridgian) larger benthic Foraminifera from Santiago Coatepec, SE Puebla, Mexico. Geobios, 41: 799-817.

Peybernès, B., Ciszak, R., Cugny, P. \& Damotte, R. 1984, Le Crétacé inférieur et moyen des Monts de Daia (Oranie, Algerie occidentale): analyse micropaléontologique et paléoécologique de l'intervalle Barremian-Cenomanien. Geologie Mediterraneenne, 11 (2): 147-158.

Riegraf, W. 1988, Callovian (Middle Jurassic) benthonic foraminifera from Southwest Germany. Revista Española Micropaleontología, 20 (3): 451-490.

Riegraf, W., Luterbacher, H. 1989a, Oberjura-Foraminiferen aus dem Nord- und Sudatlantik (Deep Sea Drilling 
Project Leg 1-79). Geologische Rundschau, 78 (3): 9991045.

Riegraf, W., Luterbacher, H. 1989b, Benthonische SchelfForaminiferen aus dem Valanginium-Hauterivium (Unterkreide) des Indischen Ozeans sudwestlich Madagaskar (Deep Sea Drilling Project Leg 25, Site 249). Geologische Rundschau, 78 (3): 1047-1061.

Reuss, A.E. 1846, Die Versteinerungen der Böhmischen Kreideformation. Abhandlungen 1 Part II: 1-148, Stuttgart.

Schlagintweit, F., Ebli, O. 1999, New results on microfacies, biostyratigraphy and sedimentology of Late Jurassic Early Cretaceous platform carbonates of the Northern Calcareous Alps. Part I: Tressenstein Limestone, Plassen Formation. Abhandlumgen der Geologischen Bundesanstalt, 56 (2): 379-419.

Schlagintweit, F., Gawlick, H-J., 2008, The occurrence and role of microencruster frameworks in Late Jurassic to Early Cretaceous platform margin deposits of the Northern Calcareous Alps (Austria). Facies, 54: 207-231.

Schlagintweit, F., Gawlick, H.-J. \& Lein, R. 2005, Mikropaläontologie und Biostratigraphie der PlassenKarbonatplattform der Typlokalität (Ober-Jura bis Unter-Kreide, Salzkammergut, Österreich). Journal of Alpine Geology, 47: 11-102.

Schmalzriedt, A. 1991, Die Mikrofauna in Schwammen, Schwammriff- und "Normal" - Fazies des unteren und mittleren Malm (Oxfordium und Kimmeridgium, Ober Jura) der westlichen und mittleren Schwäbischen Alb (Wurttemberg). Tübinger Mikropaläontologische Mitteilungen, 10: 1-120.

Schmid, D.U., Leinfelder, R.R. 1996, The Jurassic Lithocodium aggregatum-Troglotella incrustans foraminiferal consortium. Palaeontology, 39: 21-52.

Senowbari-Daryan, B., Bucur, I.I., Schlagintweit, F., Săsăran, E. \& Matyszkiewicz, J. 2008, Crescentiella, a new name for „Tubiphytes" morronensis Crescenti, 1969: an enigmatic Jurassic-Cretaceous microfossil. Geologia Croatica, 61 (2-3): 185-214.

Septfontaine, M. 1974, Présence de Protopeneroplis trochangulata sp. nov. (Foraminifère) dans le Crétacé inférieur du Jura méridional et révision de Protopeneroplis Weynschenk, 1950. Eclogae Geologicae Helvetiae, 67 (3): 605-628.

Septfontaine, M. 1977, Niveaux à Foraminifères (Pfenderininae et Valvulininae) dans le Dogger des Préalpes médians du Chablais occidental Haute-Savoie, France). Eclogae Geologicae Helvetiae, 70: 599-635.

Septfontaine, M. 1980, Les foraminifèrs des milieux de plate-forme au Mésozoique: Détermination pratique, interprétation phylogenetique et utilization biostratigraphique. Revue de Micropaléonlogie, 23 (3-4): 169-203.

Septfontaine, M. 1988, Vers une classification évolutive des Lituolidés (Foraminifères) jurassiques en milieu de plate-forme carbonatée. Revue de Paléobiologie, Spec. vol. 2, Benthos'86: 229-256.

Słomka, T. 1986, Sedimentation of the Cieszyn Beds; statistic analyses. Annales Societatis Geologorum Poloniae, 56: 277-336 (in Polish with English summary).

Soták, J. 1987, Protopeneroplide foraminifers from Lowermost Cretaceous of the Štramberk carbonate platform (Outer western Carpathians) Geologica Carpathica, 38 (6): 651-669.

Soták, J., Mišík, M. 1993, Jurassic and Lower Cretaceous dasycladalean algae from the western Carpathians. In Studies on Fossil Benthic Algae. (Barattolo et al., Eds). Bollettino della Società Paleontologica Italiana, Spec. vol., 1: 383-404.

Świdrowska, J., Hakenberg, M., Poluhtovič, B, Seghedi, A \& Višnâkov, I. 2007, Evolution of the Mesozoic basins on the south western edge of the East European Craton (Poland, Ukraine, Moldova, Romania). Studia Geologica Polonica, 130 (1): 3-130.

Tasli, K. 1993, Micropaléontologie, startigraphie et environnemental de dépôt des séries jurassiques á facies de palte-forme de la région de Kale-Gümüshane (Pontides orientales, Turquie). Revue de Micropaléontologie, 36 (1): 45-65.

Urbaniec, A., Świetlik, B. 2003. Verification of stratigraphy of Upper Jurassic and lower part of Lower Cretaceous in middle part of the Carpathian foreland in the light of new micropalaeontological data. Tomy Jurajskie 1: 105-110 (in Polish).

Urbaniec, A., Bobrek, L. \& Świetlik B. Lithostratigraphy and micropalaeontological characteristic of Lower Cretaceous strata in the central part of Carpathian Foreland. Przeglad Geologiczny (in Polish with English summary) (in review).

Vašíček, Z., Michalík, J. \& Reháková, D., 1994, Early Cretaceous stratigraphy, palaeogeography and life in Western Carpathians. Beringeria, 10: 3-169.

Velić, I. 2007, Stratigraphy and Palaeobiogeography of Mesozoic Benthic Foraminifera of the Karst Dinarides (SE Europe). Geologia Croatica, 60 (1): 1-113.

Voznesenskii, A., Gorbachik, T. \& Kuznetsova, K. 2002, Jurassic and Cretaceous Sea basins in the Southeastern part of the Lesser Caucasus: Sedimentation Settings and Foraminiferal Assemblages. Stratigraphy and Geological Correlation, 10 (3): 53-66 (in Russian).

Weidich, R. 1990, Die kalkalpine Unterkreide und ihre Foraminiferenfauna. Zitteliana, 47: 3-312.

Weynschenk, R. 1950, Die Jura-Mikrofauna und -flora des Sonnwendgebirges (Tirol). Schlern-Schriften, Universität Innsbruck, 83: 1-32.

Weynschenk, R. 1956, Some rare Jurassic index foraminifera. Micropaleontology, 2 (3): 283-286.

Yokoyama, M. 1890, Foraminiferen ous dem Kalksteine von Torinosu und Kompira. In Zur Geologie und Palaontologie von Japan (Neumann, E., Neumayr, M., Eds.). Denkschrift Kaiserische Akademie der Wissenschaft MathemathikNaturwissenschaft Classe, 57: 26-27.

Zdanowski, P., Baszkiewicz, A. \& Gregosiewicz, Z. 2001, Facies analysis of the uppermost Jurassic and the Lower Cretaceous deposits in the Zagorzyce region (southern Poland). Przeglad Geologiczny, 49 (2): 161-178 (in Polish with English summary).

Zedler, B. 1961, Stratigraphische Verbreitung und Phylogenie von Foraminiferen des nordwestdeutschen Oberhauterive. Palaeontologische Zeitschrift, 35 (1-2): 28-61. 


\section{Plate 1.}

Fig. 1. Verneuilinoides sp. (Gródek nad Dunajcem, UJ 140 P/99, x 35).

Figs. 2-5. Verneuilinoides neocomiensis (MJATLIUK) (2-3. Lusina, UJ 140P/39; 4-5. Woźniki, UJ 140P/31).

Figs. 6-8. Redmondoides lugeoni (SEPTFONTAINE) (6. Gródek nad Dunajcem, UJ 140 P/78; 7. Woźniki, UJ 140P/31; 8. Gródek nad Dunajcem, UJ 140 P/158).

Figs. 9, 10. Gaudryinopsis sp. (8. Lusina, UJ 140 P/39; 9. Zamarski, UJ 140 P/36).

Figs. 11, 12. Protomarssonella kummi (ZEDLER) (10. Lusina, UJ 140 P/67; 11. Gródek nad Dunajcem UJ 140P/91).

Fig. 13. Valvulinidae indet. (Leńcze, UJ 140 P/73).

Figs. 14, 15. Ammobaculites subcretaceus CUSHMAN \& ALEXANDER (14. Zamarski, UJ 140 P/36, x 35; 15. Lusina, UJ 140P/52, x 35)

Fig. 16. Arenobulimina sp. (Woźniki, UJ 140P/31).

Fig. 17. Haghimashella arcuata (HAEUSLER) (Gródek nad Dunajcem, UJ 140 P/109).

Fig. 18. Plectinella sp. (Gródek nad Dunajcem, UJ 140 P/109).

Fig. 19. Siphovalvulina variabilis SEPTFONTAINE (Woźniki, UJ 140P/31).

All figures x 90, except otherwise stated. 

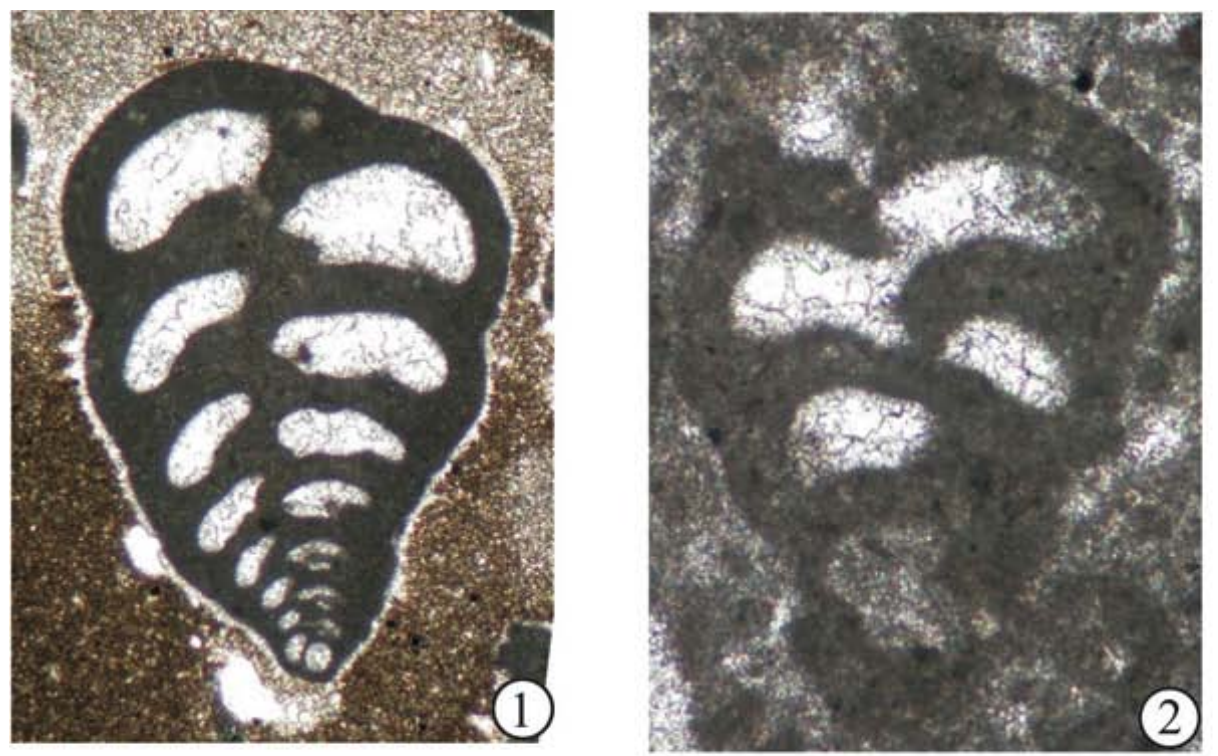

PLATE I
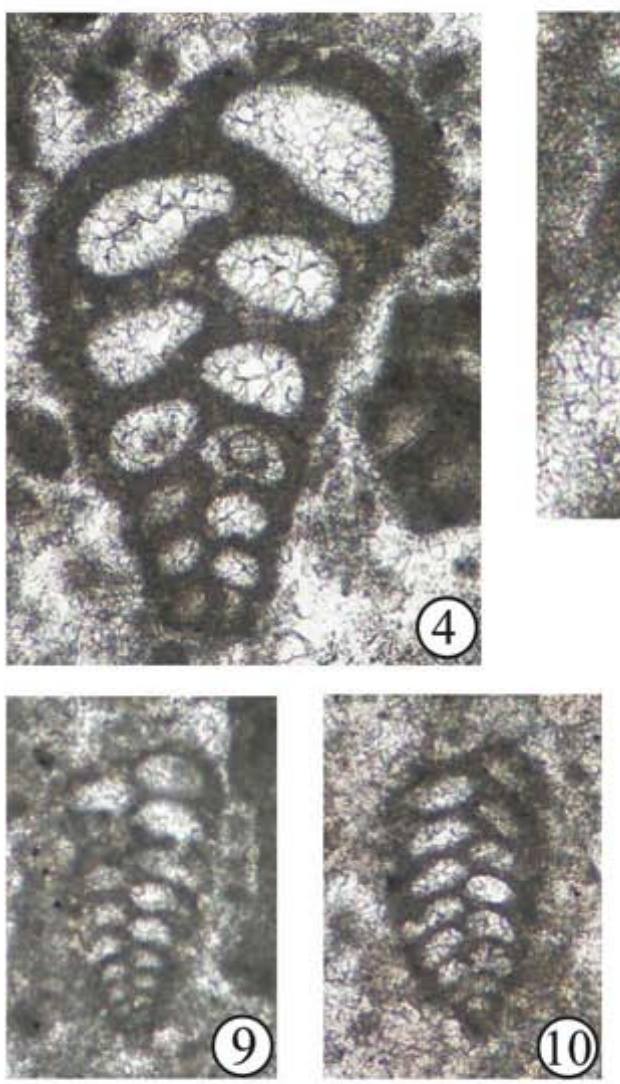

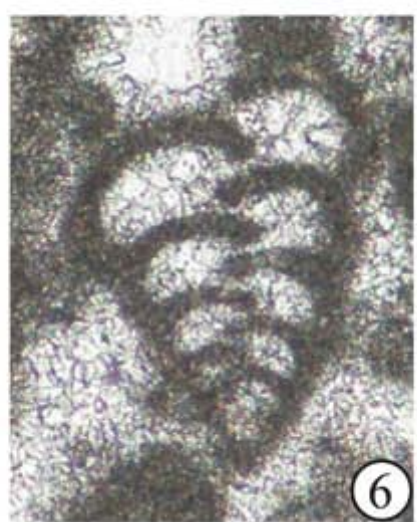

(6)

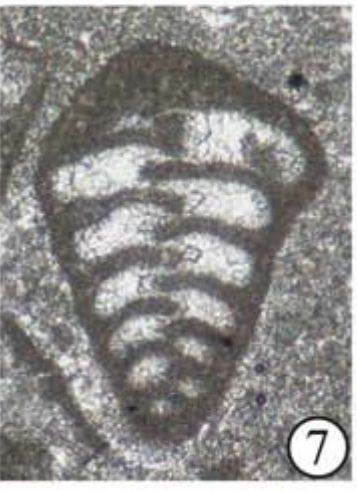

(7)

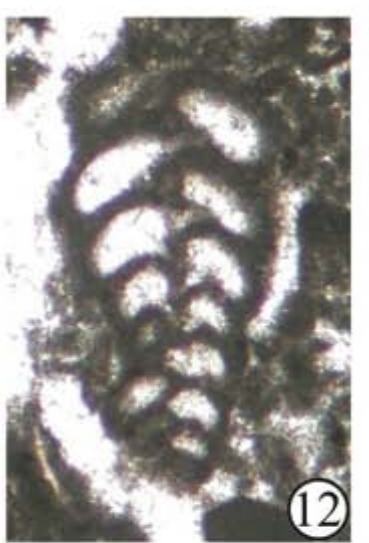

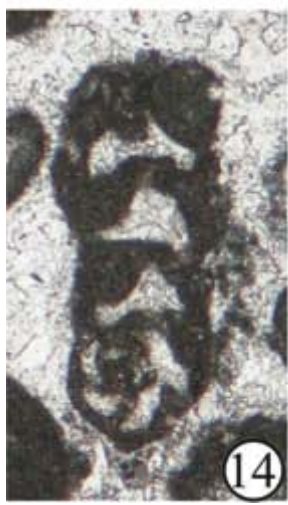
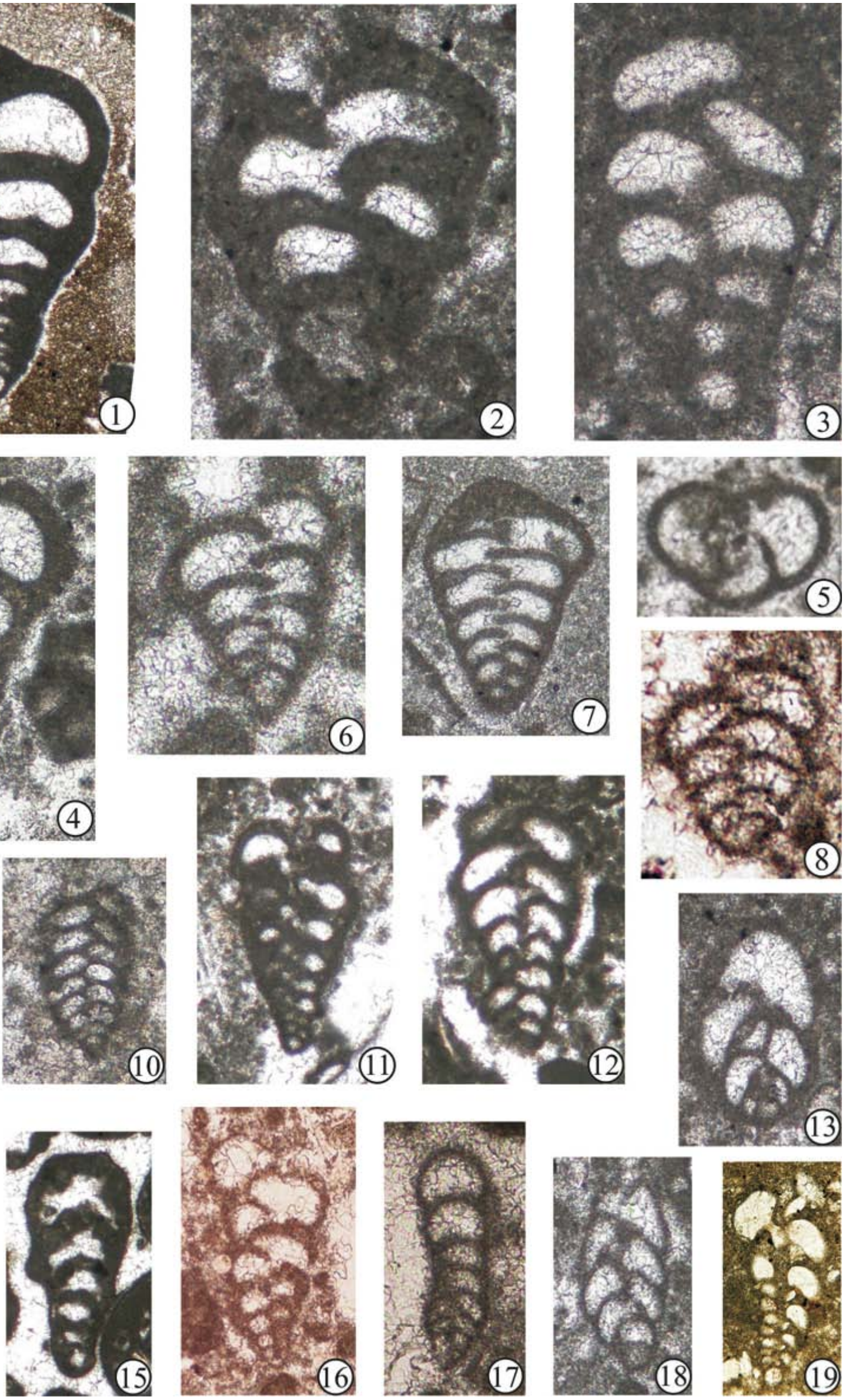

Studia UBB, Geologia, 2010, 55 (2), 3 - 31 


\section{Plate 2.}

Fig. 1. Freixialina planispiralis RAMALHO, 1969 (Woźniki, UJ 140P/31).

Figs. 2-4. Nautiloculina bronnimanni ARNAUD-VANNEAU \& PEYBERNES (2. Lusina, UJ 140P/52; 3. Leńcze, 140 P/73; 4 . Jastrzębia, UJ 140 P/191).

Fig. 5. Carasuella sp. (Gródek nad Dunajcem, UJ 140 P/91).

Fig. 6. Lenticulina sp. (Lusina 140P/39, x 35).

Fig. 7. Hechtina praeantiqua BARTENSTEIN \& BRAND Gródek nad Dunajcem, 140P/32.

Figs. 8, 9. Meandrospira favrei (CHAROLLAIS, BRÖNNIMANN \& ZANINETTI) (Lusina, UJ 140P/39).

Fig. 10. Montsalevia salevensis (CHAROLLAIS, BRÖNNIMANN \& ZANINETTI) (Jastrzębia, UJ 140 P/191).

Fig. 11. Mayncina cf. bulgarica LAUG, PEYBERNES \& REY (Gródek nad Dunajcem, UJ 140 P/118).

Figs. 12-15. Melathrokerion valserinensis BRÖNNIMANN \& CONRAD (12. Gródek nad Dunajcem, UJ 140 P/78; 13 . Woźniki, UJ 140 P/23; 14. Woźniki, UJ 140 P/177. 15. Gródek nad Dunajcem, UJ 140 P/100).

Figs. 16-19. Dobrogelina ovidi NEAGU (16. Gródek nad Dunajcem, UJ 140 P/110; 17-19. Gródek nad Dunajcem, UJ 140 P/100)

Fig. 20. Ophthalmidium sp., Lusina, UJ $140 \mathrm{P} / 85)$.

Fig. 21. Spirillina sp. (Woźniki, UJ $140 \mathrm{P} / 23$ ).

Figs. 22, 23. Istriloculina eliptica (IOVCHEVA) (22. Gródek nad Dunajcem, UJ 140 P/84; 23. Woźniki, UJ 140P/31).

Figs. 24-26. Istriloculina emiliae NEAGU (24. Gródek nad Dunajcem, UJ 140 P/99); 25. Gródek nad Dunajcem, UJ 140 P/82; 26. Gródek nad Dunajcem, UJ 140 P/100).

Figs. 27, 28. Moesiloculina danubiana NEAGU (27. Lusina, UJ 140P/39; 28. Woźniki, UJ 140P/31).

Figs. 29-32, 34-36. Quinqueloculina egmontensis LLOYD (29. Gródek nad Dunajcem, UJ 140 P/99; 30 . Gródek nad Dunajcem, UJ 140 P/118; 31. Jastrzębia, UJ 140 P/191; 32. Gródek nad Dunajcem, UJ 140 P/158; 34. Woźniki, UJ 140P/34; 35

Gródek nad Dunajcem, UJ 140 P/99; 36. Gródek nad Dunajcem, UJ 140 P/97).

Figs. 33, 37. Quinqueloculina multicostata NEAGU (Woźniki, UJ 140P/31).

All figures x 90, except otherwise stated.

Studia UBB, Geologia, 2010, 55 (2), 3 - 31 

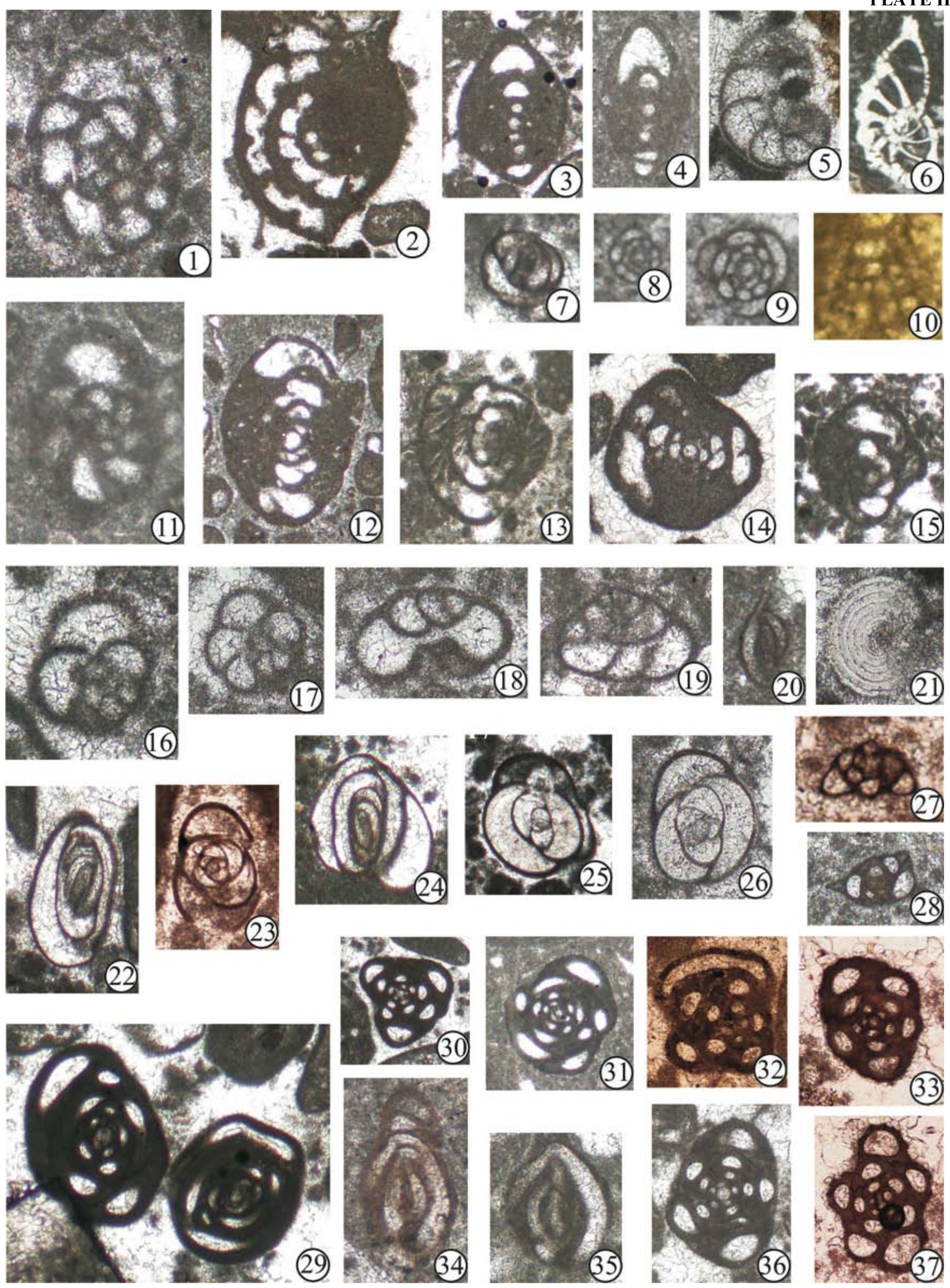


\section{Plate 3.}

Figs. 1-4. Coscinophragma cribrosum (REUSS) (1. Gródek nad Dunajcem, UJ 140 P/176; 2. Gródek nad Dunajcem, UJ 140 P/176; 3-4. Gródek nad Dunajcem, UJ 140 P/115).

All figures x 35 .

Figs. 5-10. Charentia cuvillieri NEUMANN (5. Gródek nad Dunajcem, UJ 140 P/99; 6, 8, 10. Leńcze, UJ 140 P/45; 7, 9. Leńcze, UJ 140 P/83). All figures x 90 . 

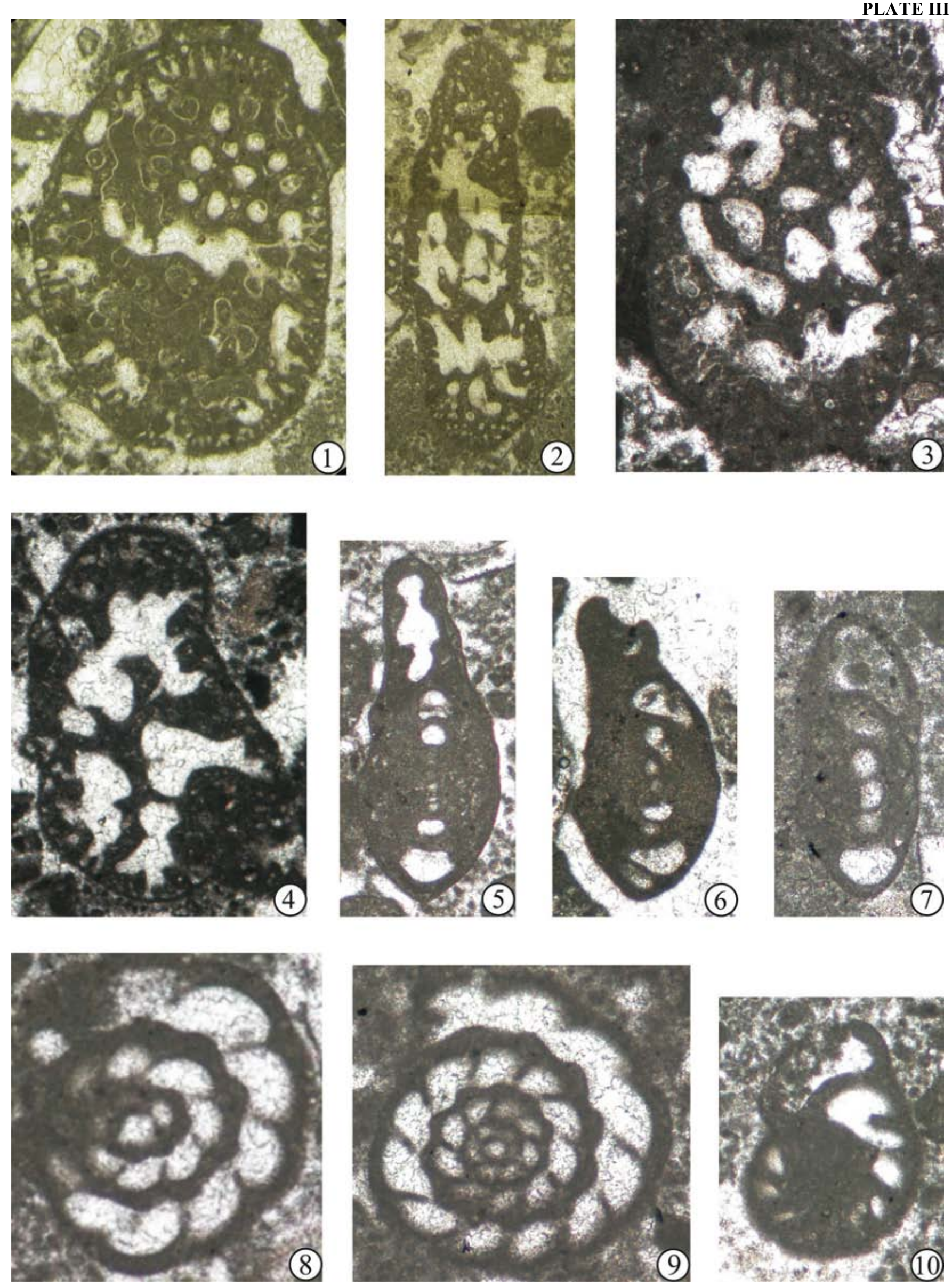


\section{Plate 4.}

Figs. 1-10. Pseudocyclammina lituus (YOKOYAMA) (1. Gródek nad Dunajcem, UJ 140 P/99; 2. Leńcze, UJ 140 P/45; 3-4, 6. Gródek nad Dunajcem, UJ 140 P/180; 5. Gródek nad Dunajcem, UJ 140 P/158; 7. Leńcze, UJ 140 P/83; 8-9. Gródek nad Dunajcem, UJ 140 P/99; 10. Woźniki, UJ $140 \mathrm{P} / 177)$. All figures x 35 .

Studia UBB, Geologia, 2010, 55 (2), 3 - 31 

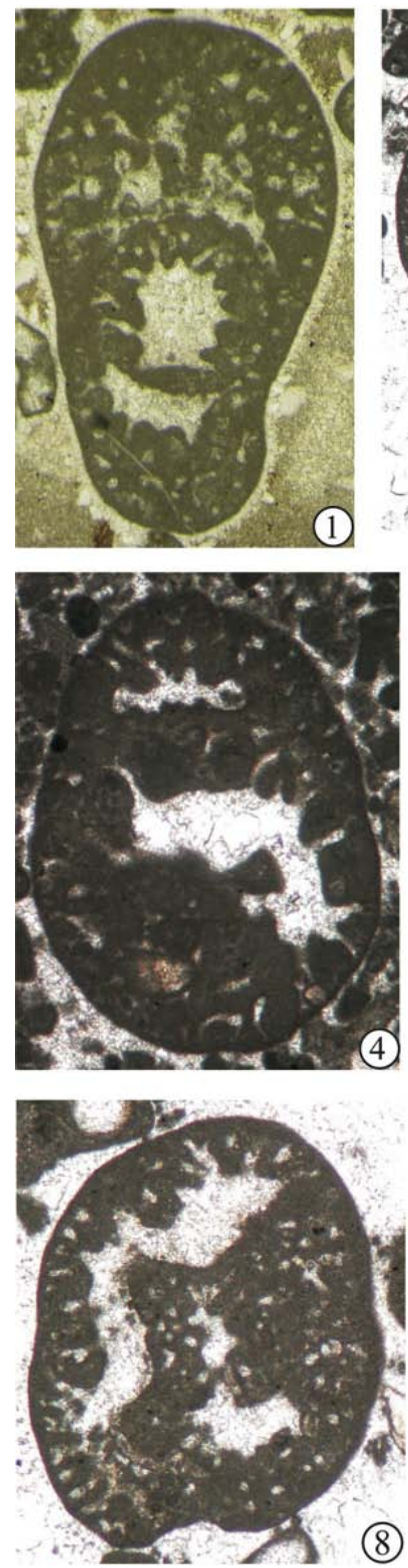
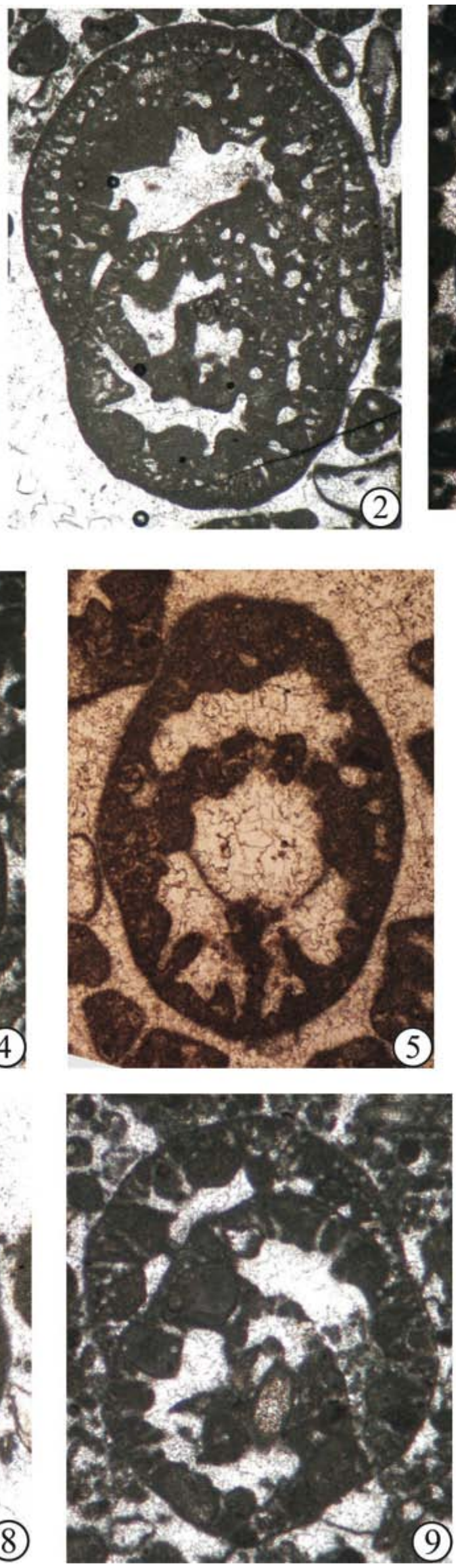
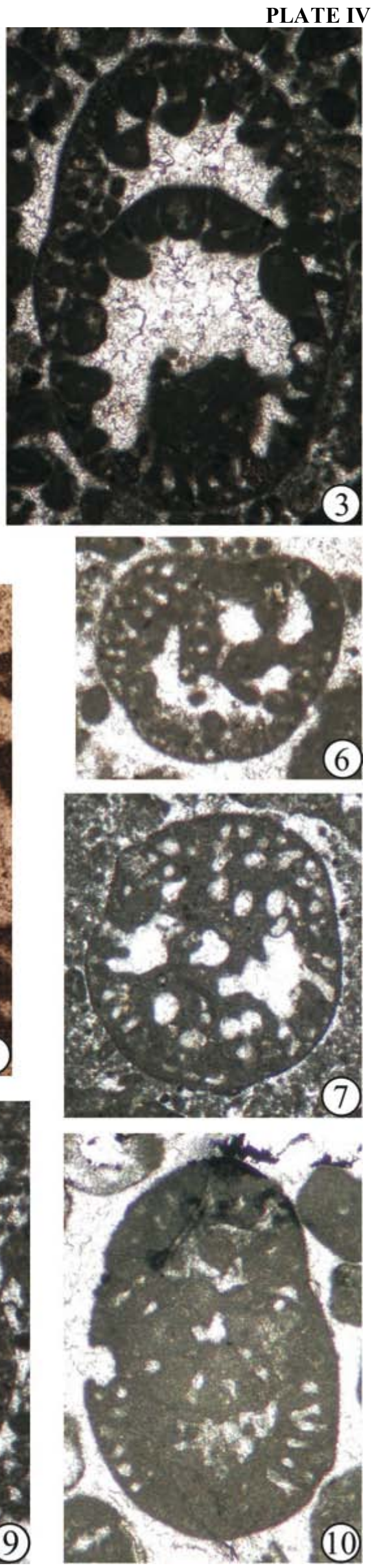
Plate 5.

Figs. 1-6. Protopeneroplis ultragranulata (GORBACHIK) (1. Gródek nad Dunajcem, UJ 140 P/99; 2. Woźniki, UJ 140P/31; 3. Gródek nad Dunajcem, UJ 140 P/90; 4. Gródek nad Dunajcem, UJ 140 P/97; 5. Gródek nad Dunajcem, UJ 140 P/79; 6. Lubenia, UJ 140 P/11).

Figs. 7, 8. Protopeneroplis striata WEYNSCHENK (Zamarski, UJ 140 P/36).

Figs. 9-11. Patellina turriculata DIENI \& MASSARI (Lusina, UJ 140P/39).

Figs. 12-18. Mohlerina basiliensis (MOHLER) (12. Gródek nad Dunajcem, UJ 140 P/84; 13. Gródek nad Dunajcem, UJ 140 P/115; 14. Gródek nad Dunajcem, UJ 140 P/158; 15. Gródek nad Dunajcem, UJ 140 P/81; 16. Gródek nad Dunajcem, UJ 140 P/99; 17 . Gródek nad Dunajcem, UJ 140 P/115; 18. Zamarski, UJ 140P/36).

Figs. 1-11 x 90, Figs. 12-18 x 35 .

Studia UBB, Geologia, 2010, 55 (2), 3 - 31 

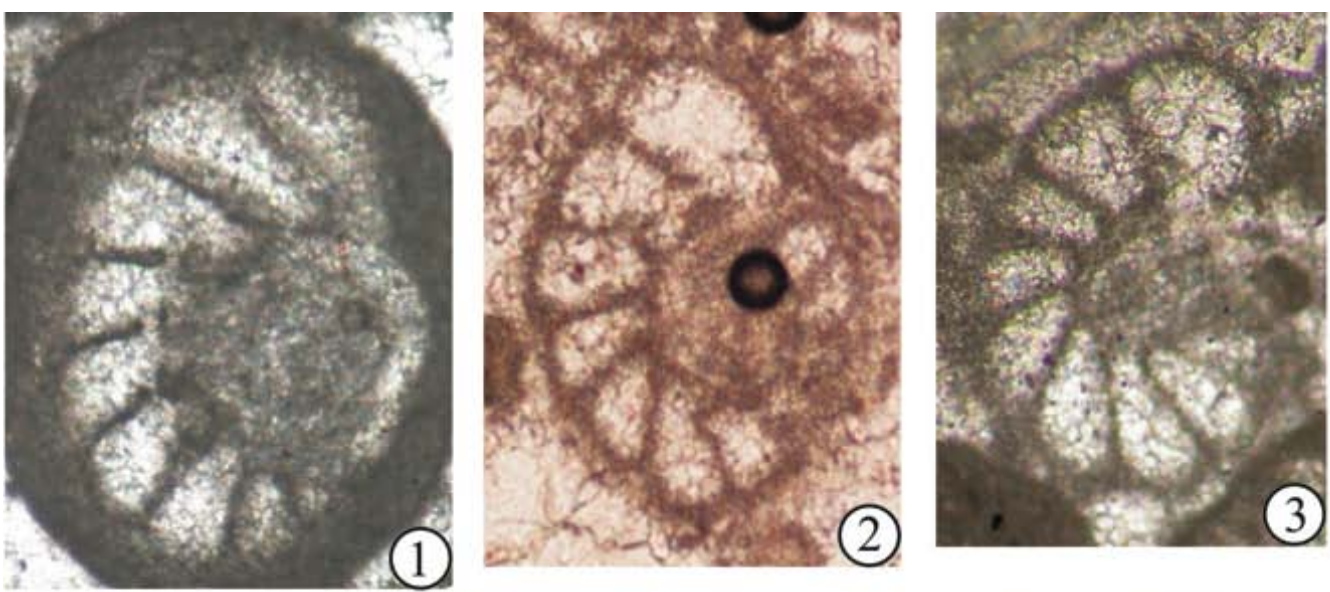

PLATE V
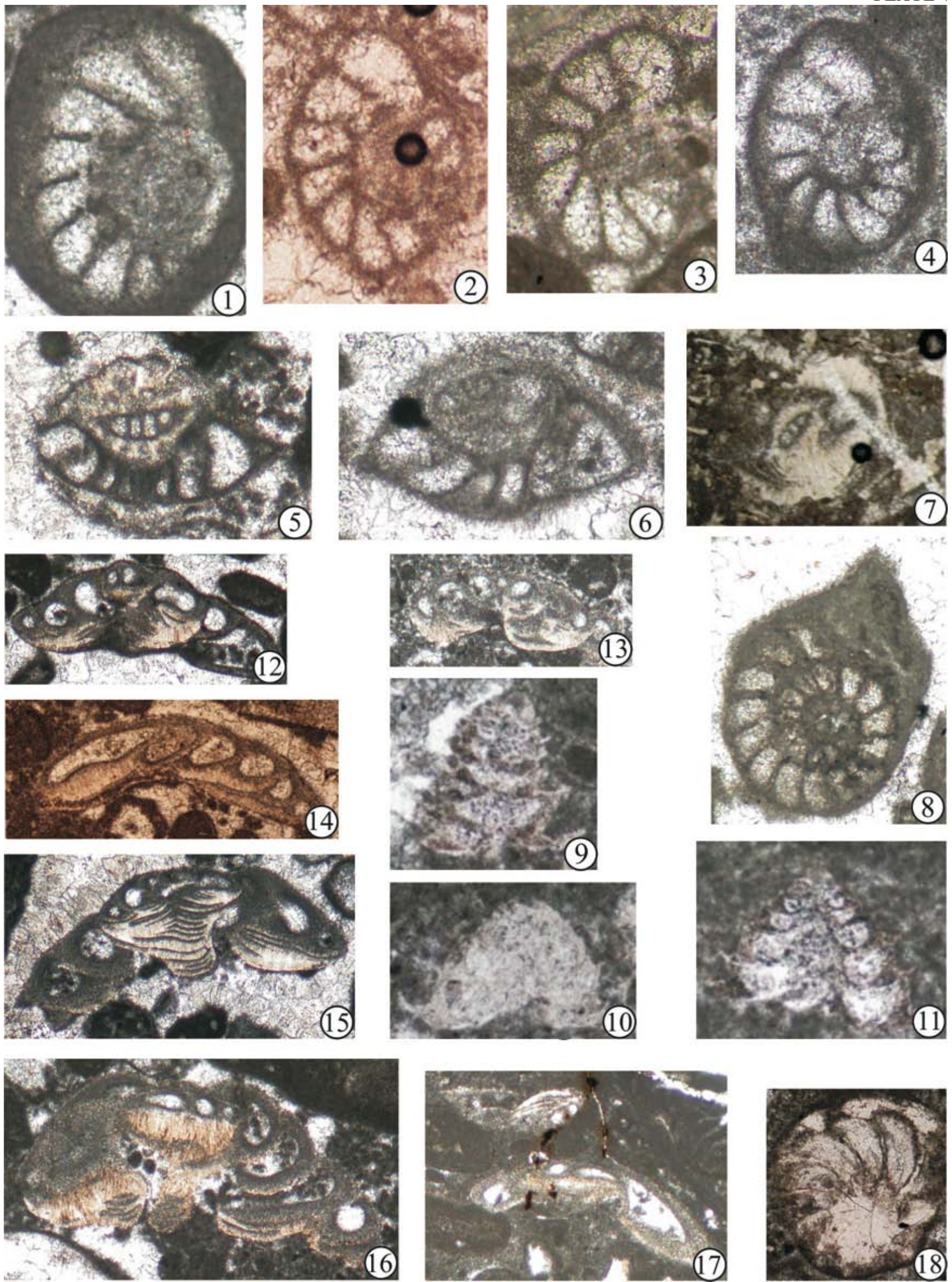

Studia UBB, Geologia, 2010, 55 (2), 3 - 31 